University of Rhode Island

DigitalCommons@URI

Open Access Master's Theses

1995

\title{
AN INDELICATE BALANCE; ECONOMIC FACTORS IN THE \\ MILITARY CAREER OF BENEDICT ARNOLD
}

Robert A. Scappini

University of Rhode Island

Follow this and additional works at: https://digitalcommons.uri.edu/theses

\section{Recommended Citation}

Scappini, Robert A., "AN INDELICATE BALANCE; ECONOMIC FACTORS IN THE MILITARY CAREER OF BENEDICT ARNOLD" (1995). Open Access Master's Theses. Paper 1813.

https://digitalcommons.uri.edu/theses/1813

This Thesis is brought to you for free and open access by DigitalCommons@URI. It has been accepted for inclusion in Open Access Master's Theses by an authorized administrator of DigitalCommons@URI. For more information, please contact digitalcommons-group@uri.edu. 
AN INDELICATE BALANCE; ECONOMIC FACTORS IN THE MILITARY CAREER OF BENEDICT ARNOLD BY ROBERT A. SCAPPINI

A THESIS IN PARTIAL FULFILLMENT OF THE REQUIREMENTS FOR THE DEGREE OF MASTER OF ARTS

IN

HISTORY

UNIVERSITY OF RHODE ISLAND 1995

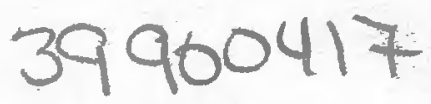




\section{ABSTRACT}

This thesis will examine Benedict Arnold's life assessing the mercenary nature of his military career in the larger context of financial gain under the guise of military operations. Arnold's actions as a continental officer and as a Eritish general became overshadowed by his act of treason, and as such, there has been no serious examination of his personal and business affairs from 1779 to 1801 .

Throughout the war Arnold was the object of several Congressional and military investigations for financial mismanagement and abuse of power. The accusations against Arnold would become secondary, as the priorities of the war superceded the need for justice. As Arnold's lifestyle exceeded his continental pay rumors of theft, financial mishandling, embezzlement and war profiteering would persist. Despite heroic actions on the battlefield Arnold could not remove the stain of impropriety. Taking up the British cause, Arnold attacked specific areas of the east coast that were centers of trade and commerce.

After the war, considered to be a refugee divorced of all his holdings, Arnold arrived in England and immediately set about building a merchant fleet that would give rise to a trading empire on both sides of the Atlantic. 


\section{TABLE OF CONTENTS}

Introduction...................

Arnold's Military Education...........

Accusations of Impropriety..........20

Saratoga and Philadelphia...........24

Turning Traitor....................

Virginia and Connecticut Operations.....442

Canadian Business Ventures..........58

Conclusion....................67

Bibliography.................73 


\section{INTRODUCTION}

In the l8th century, military officers commonly capitalized on any goods or cash plundered during the course of a campaign. Most notable was the use of privateers under a letter of marquee; however, opportunities arose during land operations when enterprising officers of all ranks could profit, from the capture of enemy territory. officers of European armies received subsidies from their families and needed additional income to help finance their life in the military.

Prize agents represented the officers, taking goods or valuables and selling them on the open market, and then paid the officers a set percentage of the selling value. Many of the great houses and manors of England were decorated with the prizes of battle and paid for with the goods taken during a campaign.

In the United States, Benedict Arnold took advantage of his rank and the exigencies of the battlefield for profit. Weighing all his options carefully, Arnold factored in his mercenary need into the strategy and execution of his campaigns. Throughout the Revolutionary War, the suspicion of misappropriation, theft, malfeasance, and embezzlement followed Arnold.

When the evidence of misuse of power against Arnold mounted, Congress was forced to act. A court of inquiry and a general court martial brought to light the periphery of 
Arnold's misconduct, and yet the findings of each inquiry merely recommended that Arnold take better care in his bookkeeping. The Continental Congress chose to keep a capable general in the field.

After switching allegiances, Arnold petitioned Cornwallis to allow him to conduct operations against Philadelphia, Virginia, and Connecticut. Appearing on paper as military targets, they were, in fact, the sites of large depots or centers of commerce. Arnold's gain from the Virginia and Connecticut incursions allowed him to retire comfortably after the war and to establish a trading company based in London and the Canadian maritime.

An examination of the life of Benedict Arnold, assessing the mercenary nature of his military career in the context of financial gain, under the guise of military operations, reveals a calculating man bent on living a life of luxury.

\section{EARLY LIFE}

Benedict Arnold was born amidst the comfortable surroundings of his father's house in Chelsea Parade in Norwich Town, Connecticut on January 14, 1741. Five Benedicts born to Hannah Waterman King Arnold did not survive past infancy. Benedict Arnold was named for his father, the third of that name who settled in Norwich Town in 1730, by trade a cooper, ship owner and sea captain, town surveyor, collector, asses- 
sor, and selectman. ${ }^{1}$

The Arnold family had close associations with Roger Williams in founding Rhode Island. The first Benedict Arnold, elected governor of Rhode Island ten times, served 15 years, the longest of any of the colony's governors. ${ }^{2}$ other Arnolds became merchants and professionals in the colony.

Young Benedict Arnold received his primary education at Doctor Jewett's one-room elementary school in the Manville section of Norwich Town and his theology at the First Church of Norwich, where his parents paid handsomely for the first pew. ${ }^{3}$

Quick, agile, and powerfully built, Arnold was a leader and an organizer, not a bully.

Exceptionally alert and intelligent but prone to exuberance, which was counterbalanced by his mother's stern piety, Benedict, enrolled by his mother, attended Doctor James Cogwell's private school 15 miles north in Canterbury, Connecticut in 1752. He took courses in English, mathematics, the Bible, language, history, and logic, an accelerated

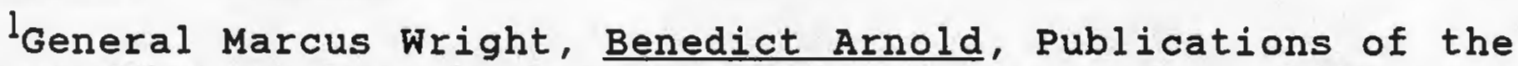
Southern History Association, Vol. 10, Number 6, Nov. 1906, pp. 363-378.

William Sterne Randall, Benedict Arnold: Patriot and Traitor, New York, William Morrow, 1990, pp. 22-23.

${ }^{3} \mathrm{Cl}$ are Brandt, The Man in the Mirror, New York, Random House, 1994, pp. 4-6.

${ }^{4}$ Frances Manwaring Caulkings, History of Norwich, Connecticut, published by author, 1866, pp. 8-10. 
education offered to sons of gentlemen of trade. 5

During Arnold's tenure at the Cogwell school, his father suffered a reversal of fortune, as his over-extended trading business sank deeper into debt. Captain Arnold consoled himself at Peck's tavern and slowly sank into an alcoholic abyss. In 1754, Captain Arnold was declared a public debtor and an arrest warrant was issued. Ordered home, young Arnold, along with his family, suffered the public humiliation of having to carry his father home from his all too frequent binges. As his father sunk lower, Arnold's behavior grew more reckless. Accounts by local townspeople described a boy in love with danger. Sneaking aboard ships at the dock, Arnold would climb the masthead and balance himself on the yardarm high above the deck. When a neighbor's barn caught fire, Arnold climbed to the top of the burning structure and balanced himself on the ridgepole. During the summer, Arnold would gather his friends at the grist mill where he would grab hold of the rungs of the waterwheel and ride it for three revolutions. On the fourth turn at the apogee, he would release himself and dive into the holding pond. 6 In 1775 , Arnold told Doctor Benjamin Rush that "I was a coward till I was 15."7 Arnold's youthful bravado would develop into

${ }^{5}$ Malcolm Decker, Sons of the Havens, New York, Antiquarian Press, 1952, p.8.

${ }^{6}$ Ibid., p. 10 .

${ }^{7}$ Dr. Benjamin Rush, Autobiography, Princeton, NJ, Princeton University Press, 1948, George W. Corner, Ed., p. 158. 
battlefield courage, and serve as an inspiration to others.

In 1754, Hannah Arnold realized the necessity of posting her son in an apprenticeship. Doctor Daniel Lathrop, a friend of the family, as well as an apothecary and physician on Washington street in New London, signed the articles of apprenticeship. ${ }^{8}$ Lathrop treated Arnold more like a son than an employee, and in seven years Arnold mastered not only the apothecary trade, but also the responsibilities of Lathrop's cargo ships.

Arnold's youthful exuberance and quest for adventure led him to enlist twice during the French and Indian war. In 1758, Arnold joined Captain Reuben Lockwood's Company of Westchester militia on its march up the Hudson to take part in the attack on Fort Ticonderoga. Much to his embarrassment Arnold had to return to Connecticut at the request of his ailing mother. In 1759, he signed on with Captain James Holmes' militia company. After three weeks of boring camp routine, Arnold left for home. A notice in the New York Gazette, May 12, 1759 describes the deserter as 18 years old, with a dark complexion, light eyes and hair. ${ }^{10}$

Dr. Lathrop hired Benedict Arnold as supercargo aboard his trading ship, and Arnold conducted business for the doctor

${ }^{8}$ Decker, Son of the Havens, p. 13.

'Randal1, Benedict Arnold: Patriot and Traitor, p. 32.

${ }^{10}$ Edward Dean Sullivan, Benedict Arnold, Military Racketeer, New York, Vanguard Press, 1932, p. 14. 
in the West Indies. 11 After Arnold's parents died in January of 1762 , Dr. Lathrop gave Arnold a large cash gift of $£ 500$ to set him up in a business of his own. One year later, Dr. Lathrop bought and turned over the Arnold family house, clear of any debts of mortgage. Arnold moved to New Haven in the spring of 1762 and set up an apothecary where he imported from London herbs, lotions, medicines, cosmetics, books, and, for the Yale medical students, surgical supplies. The engraved sign that hung in the front of the shop read: B. ARNOLD DRUGGIST, BOOKSELLER \& C, FROM LONDON. SIBI TOTIQUE. 12 Translated, this meant "For himself and everybody."

In 1763, solvent enough to purchase a forty-ton trading sloop, the Fortune, for $£ 700$, Arnold carried on a brisk trade with st. Kitts, Martinique, the Bay of Honduras, Nova Scotia, New Foundland, the St. Lawrence River Valley, Quebec, and Montreal. Arnold traded shrewdly, expanded carefully, and established a network of business associates throughout the Atlantic and Caribbean trade routes. By 1766, Arnold owned a modest fleet of three ships which made continuous loops between the colonies, London, and the Caribbean. "Arnold as a New Haven merchant poured his profits from the ships into small coastal ships and sailed off each spring up and down the

$11_{\text {Will }}$ ard M. Wallace, Traitorous Hero; The Life and Fortunes of Benedict Arnold, New York, Harper \& Brothers, 1954, p. 24.

12 Ibid, p. 26 . 
American coastline."13

Arnold, no different from other Yankee traders, circumvented customs at every opportunity. Untaxed, smuggled items became known as "Connecticut cargo."14 By 1766, Arnold was involved in an extensive smuggling operation in the Bay of Honduras. 15

Arnold's corporate ventures hit a rocky shoal. Wind and weather teamed with angry creditors, and Arnold soon found himself in debt for fl600. With six London suppliers demanding payment, Arnold dropped all image of propriety and brought his smuggled goods directly to New Haven. ${ }^{16}$

Despite these problems, Arnold had no trouble crewing his ships and keeping their loyalty with a proper measure of discipline and bonuses. However, Peter Boles, an able-bodied seaman aboard the Fortune, demanded more money, arguing that the greater the risk, the greater the reward. Boles threatened to go to the customs officer and swear out a complaint that Arnold was a smuggler. 11

Under the guise of a political mob seeking justice, the

${ }^{13}$ Brian Richard Boylan, Benedict Arnold: The Dark Eagle, New York, W.W. Norton, 1973, p. 50 .

${ }^{14}$ William S. MCClelland, Smuggling in the American Colonies, New York, Dawson \& Co., 1921, p. 83.

${ }^{15}$ Wallace, Traitorous Hero: The Hero and Fortunes of Benedict Arnold, p. 36 .

${ }^{16}$ Ibid., p. 37 .

${ }^{17}$ Sullivan, Benedict Arnold, Military Racketeer, p. 21. 
Sons of Liberty marched to the inn where Boles lived, removed him forcibly, and watched as Arnold administered 40 lashes with a rope.

By this time Arnold had involved himself both personally and financially in the Whig movement. Arnold's involvement with the Whig movement can be charted back to 1765 when he joined the most influential whig organization in America, the secret fraternity of the Free and Accepted Masons. Anti-autocratic, anti-catholic, and champions of representative government, the Masons were intercolonial, transcontinental, and able to maintain secrets. ${ }^{18}$ Arnold joined the Masons as a vehicle of convenience and of commerce, hoping that doors would be opened by mutual contacts. The vigor of whig protests to new taxation appealed to the merchant-trader side of Arnold, and aggressive political action taken by the sons of Liberty suited his volatile nature. The sons of Liberty harassed witnesses and staged torchlight marches past the judge's home after Arnold was arrested for unlawful and riotous behavior in connection with the Boles incident. Arnold and the 9 defendants were found guilty, but were fined only 50 shillings.

As the smoke and fire of Lexington and Concord became known in the colony of Connecticut, Arnold's orbit was now pushed out of the realm of the citizen-smuggler-merchant.

\section{ARNOLD'S MILITARY EDUCATION}

As the colonies moved defiantly against the English crown,

${ }^{18}$ Ibid., p. 22. 
Connecticut residents formed independent militia companies. Arnold mustered enough men from New Haven to form the Governor's second Connecticut Regiment of Foot and appointed himself captain of the Company.

Benedict Arnold was, as most American colonial officers, a self-educated military officer. He seized whatever opportunity arose, weighed the options and the outcomes, and charted a course that best served his own personal interests. Arnold knew that for an enterprising officer war was an excellent source of personal gain.

During his march to the siege around Boston, Arnold proposed to Colonel Samuel H. Parsons, military representative from Connecticut, that the weakened conditions of Fort Ticonderoga offered a unique opportunity to capture and relieve the garrison of their cannons and powder. The Connecticut commissioners authorized the plan and equipped Arnold with 10 horses, $£ 100$ in cash, and a promise of 400 men. The newly breveted Colonel Arnold galloped from Cambridge for western Massachusetts. Sharing both mutual command, as well as hatred, with Ethan Allen, the fort was taken intact.

No sooner had the capture of the fort been accomplished when Arnold proposed an attack on the forward post of st. Jean. Commandeering a schooner and two armed bateaux, Arnold launched a pre-dawn amphibious assault, capturing the garrison, a sloop, and nine bateaux.

By June of 1775, Arnold had forwarded his plan for 
invading Canada and capturing Quebec and Montreal. He noted in his letter to the Continental Congress that, as a seaport, Quebec alone received one half million bushels of grain a year. 19

Waiting for a reply, Arnold established a forward post on the Island La Motte, 15 miles from the Canadian border. At Skensboro, he bought wood planks for boatbuilding and gun carriages. Using $£ l, 388$, and $3 \mathrm{~d}$., Arnold recruited, outfitted, and fed his own troops. He recruited skilled carpenters and wheelwrights to make barracks and to strengthen portions of Fort Ticonderoga. Then Arnold ordered his men to dig up old cannon balls surrounding the fort. He also hired a grist mill to grind wheat and bake bread, and he formed a company of Rangers from local veterans to perform reconnaissance patrols into Canada, stocking the captured sailing ships from st. Jean with provisions and armament to be commissioned the first Lake Fleet of the Continental Congress. ${ }^{20}$ Arnold accomplished all of this in just four weeks.

Arnold proved himself to be one of the best field officers in the Continental Army. He could fight on land or sea, plan strategy, logistics, fortification, and gather intelligence. He captured two of Britain's most valuable fortresses, depriving the British of communication and control of a valuable frontier region and effectively neutralized

${ }^{19}$ Boylan, Benedict Arnold: The Dark Eagle, p. 53.

${ }^{20}$ Randall, Benedict Arnold: Patriot and Traitor, p. 108. 
local Indian tribes. ${ }^{21}$ But Arnold's accomplishments up to this time were not without controversy or accusations. While the Massachusetts Committee on Safety secretly authorized Arnold to seize and build enough ships to control Lake Champlain, Arnold noted in his Regimental Memorandum Book on June 24, 1775 that all requests for cash to pay his troops were refused. Arnold's confiscation of personal property grew in intensity, but it did not equal or cover the $£ 2,750$ he personally contributed for the operation in $1775 .{ }^{22}$

As an armchair strategist before the commencement of hostilities, Arnold had read of John Montresor's trek from Quebec to Maine using a series of rivers and connecting ponds. Arnold was, of course, familiar with the Quebec area from his trading days. The combination of the familiarity of the area and the established wealth of the area stimulated Arnold into producing an invasion plan of Canada. By August 15, 1775, Washington had on his desk in Cambridge Arnold's plan for an assault on Quebec. By the 20th, Washington had approved it, and by the 30th, Arnold's invasion had begun. Fifteen hundred men, recruited from the Boston siege lines, made their way north to the Kennebec River in Maine and then northwest by bateaux toward Quebec.

While on the march, Arnold invented a new kind of army

\footnotetext{
${ }^{21}$ Ibid., p. 111 .
}

${ }^{22}$ Benedict Arnold, Regimental Memorandum Book, Fort Ticonderoga Museum Bulletin, Number 14, 1981, pp. 71-80 
unit, a light infantry regiment especially adapted to longrange amphibious raids. Such a regiment of fast moving riflemen were capable of carrying out conventional open field or siege warfare, all moving by boat. Arnold fused infantry, rangers, and ships into a fast-striking force. ${ }^{23}$ This light infantry strategy would serve as a trademark for Arnold for the rest of his military career and help him capture some of the most valuable prizes of the war.

The long road to Quebec was a trail of tears, as a conspiracy of harsh weather, sabotaged maps, sickness, and shoddy boat construction reduced Arnold's fighting force by 25\% before he reached Canada. Despite his losses, Arnold refused to let an opportunity to capitalize on a short-term investment go unheeded. On October 13,1775 while enroute to Quebec, Arnold wrote letters to his Quebec business contacts, John Marvin, Captain William Gregory, and John Maynard, telling them of the situation and the strategy of the campaign, and advising them to purchase large quantities of supplies. ${ }^{24}$

The attack and subsequent siege of Quebec failed as American troops fell victim to smallpox and the British strategy of waiting for reinforcements from Nova scotia to

${ }^{23}$ R.G.L.. Rivis, Tactics and strategies of American Forces 1775-1781, Journal of the Society of Army Historical Research, volume 10, 1941, PP. 101-102.

24 James Thomas Flexner, The Traitor and the Spy, Boston, Little, Brown and Co., 1953, p. 77. 
arrive. In a last minute attack on the city, Arnold personally led a charge on a heavily fortified position and was wounded in the leg by a ricocheting musket ball. While recovering, Arnold learned that command had devolved to him with the death of General Montgomery. Arnold established his headquarters outside the city of Montreal and prepared for the withdrawal of American forces south of the falls of the Richelieu River, between Chambly and St. Jean. ${ }^{25}$

The Northern Army of the Continental Line was in rags by the winter of 1776, reduced in numbers to a bare force, and living off whatever food could be found. Meanwhile, Arnold was entertaining the Congressional delegation of Benjamin Franklin, Samuel Chase, and Charles Carroll at his Montreal chateau. Carroll, the richest man in America, commented on the elegant feast that was put on for them by Arnold. In a letter to his father, he wrote:

"We were served with a glass of wine while people were crowding in to pay their complements: which ceremony being over, we were shown into another apartment, and unexpectantly met in it a large number of ladies, most of them French. After drinking tea, and sitting some time, we went to an elegant supper."

Arnold's mercenary nature seems to have become the primary driving force in his motivation at this time. Arnold moved about Montreal, which had been untouched by the siege of

${ }^{25}$ Charles Henry Jones, History of the Campaign for the Conquest of Canada in 1776, Philadelphia, 1882.

${ }^{26}$ Kate Rowland, Life of Charles Carroll, New York, 1898, Volume 1, p. 215 . 
moved about Montreal, which had been untouched by the siege of Quebec, carefully observing the locations of food, furnishings, and cash of the large Anglo-French merchant and trader population. ${ }^{27}$ By May 31, 1776, Arnold knew that the Canadian adventure would soon be over and moved quickly to seize all property and possession from the towns around. Montreal that were of value. Moses Hazen, a Canadian Loyalist who would eventually turn rebel, wrote that "the Americans plundered my estate of livestock, grain, tools, and everything moveable."128 As Arnold signed the Quebec withdrawal order, widespread seizures of property occurred. James Wilkenson, Arnold's aide-de-camp, was directed by Arnold himself to seize specific merchandise listed as property of the inhabitants. Wilkenson refused, for which Arnold called him "more nice than wise." Arnold dispatched another officer, Major Scott, with a large consignment of seized personal property to be impounded at the American depot at Chambly. ${ }^{29}$

Moses Hazen was the Continental Army's depot master at Chambly. He immediately recognized the material that had arrived from Arnold as property of his Montreal friends. Hazen refused to accept or take responsibility for the goods. Left outside the depot, unguarded, the boxes were broken into

\section{${ }^{27}$ Sullivan, Benedict Arnold, Military Racketeer, p. 76.}

${ }^{28} \mathrm{Al} 1$ an $\mathrm{S}$. Everest, Moses Hazen and the Canadian Refugees in the American Revolution, Syracuse University Press, Syracuse, NY, 1976, p. 32 .

${ }^{29}$ Sullivan, Benedict Arnold, Military Racketeer, p. 76. 
and plundered. Arnold berated Colonel Hazen in a letter to General sullivan. "This is not the first or last order Col. Hazen has disobeyed. I think him too much consequences for the post he is in." 30

Letters from the Anglo-French merchants and local Tories in Montreal describing the excessive and aggressive nature of Arnold's seizures began reaching Congress. In June of 1776 , Arnold wrote to Congress that "the goods were seized in accordance with orders for the use of the army was not questioned, but a vast discrepancy between the amounts and values seized and bought, as compared with the goods subsequently available to the American Army, led to bitter charges and recriminations." 31

In the same letter Arnold explained how the ends justified the means. "In the first instance, under military necessities of the moment, the goods were taken so abruptly that proper receipts were not given for the materials and the only guarantee of recognition for the owner was his name." 32 Arnold corresponded with General Schuyler from St. Jean on June 13, 1776 and stated that the goods were plundered as a result of inadequate storage. This explanation might have

${ }^{30}$ Everest, Moses Hazen and the Canadian Refugees in the American Revolution, p. 39.

${ }^{31}$ Journals of the Continental Congress 1774-1789, Library of Congress, Government Printing Office 1910, Washington, D.C., Volume $\mathrm{x}, 1776$, p. 121 .

${ }^{32}$ Ibid., p. 122 . 
been feasible considering the disorderly withdrawal from Montreal, except that goods of great value, including silks and other material in no way identified with army requirements, had been taken from merchants on Arnold's orders. ${ }^{33}$

In an effort to appease the would-be Canadian allies, Congress directed Washington to conduct inquiries into the behavior of all officers accused of "cowardice, plundering, embezzlement of public moneys, and other misdemeanors." 34 Throughout the summer of 1776, General Horatio Gates, commander of the northern army, held a succession of military trials at Fort Ticonderoga. One of the trials was the court-martial of Colonel Moses Hazen, under arrest on charges brought by Colonel Benedict Arnold. The general court-martial convened July 19, 1776, with Colonel Enoch Poor as president and Major Scott as Judge Advocate. Based on evidence supporting Hazen's record and behavior while at the chambly depot, all charges and specifications against him were dropped. Hazen would spend the next year accusing Arnold of plundering Montreal merchants for his own gain.

Another point of contention involved Major John Brown, who brought thirteen charges of gross irregularities against Arnold in connection to the plundering in Montreal. ${ }^{35}$ But

${ }^{33}$ General Philip Schuyler, Papers, National Archives, M860, Roll 142, 1776-1777, Item 42 .

${ }^{34}$ Everest, Moses Hazen and the Canadian Refugees in the American Revolution, p. 45.

${ }^{35}$ Wallace, Traitorous Hero, p. 122. 
Arnold was by this time politically connected to the influential Charles Carroll, who, as chief commissioner in charge of the investigation, ruled that he was entirely satisfied with Arnold's character and conduct. ${ }^{36}$ However, James Wilkenson continued to publicly criticize Arnold's wanton pillaging of Montreal and recorded in his memoirs that Arnold stripped Montreal and the surrounding countryside and pocketed the proceeds. ${ }^{37}$

The goods from Montreal surfaced from time to time. While courting Miss Elizabeth DeBlois, the 16-year-old daughter of a Boston Tory, Arnold sent a trunk of silk gowns as a way of reaching the reluctant girl. In a letter dated March 4, 1777 to Mrs. Henry Knox who was acting on Arnold's behalf, he wrote, "I have taken the liberty of enclosing a letter to the heavenly Miss DeBlois, which I beg favour of your delivery with the trunk of gowns."38 Miss DeBlois rejected both the trunk and the advances of the 34-year-old Arnold. Mrs. Knox wrote to her husband that "Miss DeBlois has positively refused to listen to the general which, with other mortifications, will come hard on him." 39

By mid-March 1777, Arnold became embroiled in another of

${ }^{36}$ Wallace, Traitorous Hero, p. 122.

${ }^{37}$ James Wilkenson, Memoirs of My Own Times, Philadelphia, Abraham Smal1, 1816, Volume I, p. 229.

${ }^{38}$ Benedict Arnold to Mrs. Henry Knox, March 4, 1777, Manuscript Division, Boston Public Library, Copley Branch, Boston, MA.

${ }^{39}$ Flexner, Traitor and Spy, p. 218. 
leading, and preventing disaster on the steps of quebec, Arnold received word that Congress had passed him over for promotion and appointed five major-generals: Lord stirling (William Alexander), Thomas Mifflin, Arthur St. Clair, Adam Stephen, and Benjamin Lincoln. Each newly appointed general came with his own set of foibles and a record of mediocrity on the battlefield. ${ }^{40}$

By passing over Arnold, Congress had exercised its prerogative with the Baltimore Resolutions, passed in February 19, 1777, that provided "in voting for general officers, a due regard shall be had in line of succession, the merits of the person proposed, and the quota of troops raised."4l But Arnold's behavior had hardly been calculated to win friends in his support, and in Congressional debates, which were described as perplexed, inconclusive, and irksome, one can be reasonably sure that Arnold's shortcomings were fully exploited.

Arnold, publicly humiliated by the slight, wrote a series of letters to Washington expressing his distress and bewilderment. ${ }^{42}$ For Arnold, the only recourse lay in presenting

${ }^{40}$ Colonel Mark M. Boatner, Encyclopedia of the American Revolution, David Mckay Company, 1966, Courtmartial of Arnold, p. 26.

"1. Continental Congress, Journals, worthington C. Ford, Ed., 1904-37, Volume VI, p. 237.

${ }^{42}$ Benedict Arnold, Correspondence, Letters to Washington, February-March 1777, American Manuscript Restoration Division, Library of Congress. 
ment. ${ }^{2}$ For Arnold, the only recourse lay in presenting himself to Congress at Philadelphia and demanding an explanation.

Enroute to Philadelphia, Arnold stopped in New Haven to visit friends and business associates. In the early hours of April 26, 1777, a messenger from General David Wooster woke Arnold to inform him that a British invasion was underway. William Tryon, British governor of New York, landed with 2000 men at Compo, four miles east of Norwalk, Connecticut. His troops included veterans of the 4 th, 5 th, $23 \mathrm{rd}, 27 \mathrm{th}, 44 \mathrm{th}$, and the 64th Regiments of Foot, Dragoons, and artillery detachments, and the Tory Prince of Wales Regiment. ${ }^{43}$ Their objective was to move quickly inland, and capture and destroy the American supply depot at Danbury, Connecticut.

Arriving on the scene, Arnold set about organizing the militia troops and fighting a rear guard action as the British force marched back to their ships. By doing this, Arnold limited the invasion force to a small corridor. Leading one of the several frontal assaults against a musket line from the 64 th Regiment, Arnold's horse was killed by a musketball. About to be captured, Arnold freed his saddle pistol and killed a charging British soldier. Mounting another horse,

${ }^{42}$ Benedict Arnold, Correspondence, Letters to Washington, February-March 1777, American Manuscript Restoration Division, Library of Congress.

${ }^{43} \mathrm{~J} . W$. Fortescue, History of the British Army, London, McMillian \& Company, 1911, Volume III, p. 358. 
Arnold directed the construction of a barricade across the line of retreat and held them until a relief column of Royal Marines cut out an avenue of escape.

For Arnold's behavior in the field, an American officer commented that he saw Arnold "with the greatest intrepidity and coolness even to the best language under the most aggravating circumstances." 44 Congress, embarrassed by Arnold's latest act of heroism, promoted him to the rank of majorgeneral, but withheld his seniority so that he was still junior to the five generals promoted in March.

\section{FURTHER ACCUSATIONS OF IMPROPRIETY AGAINST ARNOLD}

Arnold arrived in Philadelphia on May 20, 1777, and walked straight into a new barrage of accusations regarding his actions as commander of American forces outside Quebec. John Brown, a Pittsfield, Massachusetts native and a Yaleeducated lawyer who became deeply involved in whig politics after graduation, was the principal architect of these accusations. In 1775, Brown volunteered to be part of the capture of Fort Ticonderoga and volunteered for the Canadian invasion. Commissioned a major in Easton's regiment, he rose to the rank of colonel by 1777 and continued to serve as staff officer with Elmore's Connecticut Regiment during the Quebec campaign. ${ }^{45}$ Arnold cited him for insubordination on two occasions but did not remove him from the Canadian operations

\footnotetext{
${ }^{44}$ Boylan, Dark Eagle, p. 251.

${ }^{45}$ Boatner, Encyclopedia of the American Revolution, p. 116.
} 
because of Brown's friendship with General Richard Montgomery. Brown resigned his commission in February 1777 and returned to Pittsfield to practice law, accepting a position in 1779 on the bench in the county court of common pleas. However, his main mission in life was to bring to light the crimes committed by Benedict Arnold. Brown wrote and subsidized the printing of a pamphlet narrating his experiences while in Canada. In his pamphlet Brown made the accusation of Arnold that "money is this man's god and to get it he would sacrifice his country." $" 46$

In conjunction with the publication and distribution of the pamphlet, Brown sent a letter to Congress and General Horatio Gates demanding a court of inquiry Brown's letter detailed thirteen charges covering a wide area of personal and professional improprieties committed by Arnold.

Brown began his indictment by describing the ill treatment he received by Arnold. He characterized these attacks as personal, vindictive, and ungentleman-like.

The central theme of Brown's accusations centered around Arnold's behavior during the Canadian campaign. He accused Arnold of plundering the inhabitants of Montreal, giving unjustifiable, unwarrantable, cruel, and bloody orders directing whole villages to be destroyed and the residents put to the sword.

${ }^{46}$ J.E.A. Smith, History of Pittsfield, Boston, 1869, Volume 1, p. 225 . 
In addition to theft and plunder, Brown contends that while commanding the Continental Fleet on Lake Champlain Arnold insulted his superior officers and disobeyed orders from the Massachusetts Committee. ${ }^{47}$

While some of the thirteen charges made by Brown are superfluous, charges regarding the plunder of Montreal need to be examined.

American forces had controlled large areas of territory surrounding both Quebec and Montreal. During the latter part of the siege, American forces moved against several towns and villages along the St. Lawrence River. In May of 1775, after recovering from wounds received during the attack on Quebec, Arnold returned to the Montreal area of operation and ordered Colonel J.P. DeHaas to "destroy Conosadaga and all people within it." 48 Arnold also ordered the sacking and destruction of st. Anne, which served as the headquarters and depot for Forster's Canadian Regiment, and the town of Longueuil that was a trading center on the river. ${ }^{49}$ Arnold justified his actions to the Congressional Commission, and in return the commissioners wrote that "the seizure, in exchange for promise of pay, of goods and supplies absolutely required for the

${ }^{4 i}$ Decker, Son of the Havens, p. 119.

${ }^{48} \mathrm{Justin}$ Smith, Our struggle for the Fourteenth Colony, Canada, and the American Revolution, New York, G.P. Putnam \& Sons, 1907, p. 357 .

${ }^{49}$ Ibid. , p. 358 . 
immediate wants" are acceptable for "your command."50

As American forces expanded their operations, goods accumulated at the Chambly depot. The seizure of goods by the occupying forces was justified on two grounds: (1) that it prevented the troops from getting food by miscellaneous plunder, thus preventing bloodshed, and (2) the owners had forfeited all claims to protection by acting or conspiring against the Americans. 51

Arnold's theft of Canadian merchandise would also enable him to purchase a full share in the sloop General McDougall that carried 10 guns and a crew of 30.52 Arnold claimed that all material confiscated or commandeered received a proper evaluation and assessment and was paid for in Continental paper money.

Through the American army network, goods were forwarded to st. Jean-Sur-Richelieu for processing, examination, and storage. Here Arnold's aides, Matthew Clarkson and David Salisbury, intercepted valuable items and placed them with Arnold's baggage train. Both aides had reputations that drew comments from even Thomas Jefferson. He characterized them as

${ }^{50}$ Jared Sparks, Correspondence of the American Revolution, Number I, Commission to Headquarters, May 26, 1776, Item 518, Special Documents, Library of Congress.

${ }^{51}$ George Hill, Benedict Arnold, Boston, 1858, p. 209.

${ }^{52}$ Flexner, Traitor and Spy, p. 221. 
"suspicious and trifling." 53

By July of 1777, the storm of controversy surrounding Arnold had passed like a summer squall and the larger events of the war pushed aside the accusations of John Brown. Later in the month, Arnold joined General Philip schuyler in the Northern Department of the Army.

ARNOLD'S ACTIONS AT THE BATTLE OF SARATOGA AND HIS MILITARY GOVERNORSHIP OF PHILADELPHIA

Wrapped in the mantle of previous political and military victories, Arnold reported for duty under his old mentor and friend, Horatio Gates. In the battlefields of northern New York, against the advancing Burgoyne, Arnold's star rose to its zenith. Off the field, Arnold and Gates clashed frequently until Arnold was relieved of command for insubordination. Enraged, Arnold mounted his horse and charged into the thick of the battle at Saratoga. With troops rallied from different parts of the battlefield, Arnold threw himself against a Hessian fortified redoubt, pushing the defenders back and cutting a hole in the line for the Americans. The consequences of his actions that day earned him a musketball in the same leg that had been wounded in Quebec.

Arnold made the painful journey from the field hospital, to Albany, and then to New Haven. Bone splinters and an open, seeping wound made his recovery painfully slow. But Arnold

${ }^{53}$ Peter Force, American Archives, Library of Congress, 4th Series, Washington, DC, 1837-1853, Number 4, Item 493. 
could not remain idle for long, and in the spring of 1778 , he travelled to Valley Forge and asked Washington to return him to active duty. Washington, having seen that it took four orderlies to assist Arnold out of a carriage and into headquarters, questioned Arnold's ability to return to duty before he was fully recovered. A persistent Arnold convinced his commander-in-chief that he would accept a rear echelon position until he could return to the field. Arnold then received the position of military governor of Philadelphia, as Washington's sources in Philadelphia knew that General Howe and the British forces planned to evacuate that city shortly.

Philadelphia occupied by the British since September 22, 1777, bulged with supplies and war material, of which the British could only remove a small fraction. ${ }^{54}$ The goods crammed into the stores, warehouses, and makeshift depots were worth their weight in gold to the rag-tag American army. Congress directed Washington "to prevent the removal, transfer, or sale of goods, wares, merchandise, in possession of the inhabitants, until the property of the same" could be "ascertained by a joint committee" that could "determine whether any or part thereof" belonged "to the King of Great Britain or any of his subjects."

On the 18th of June 1778 American forces moved in to reclaim the city. Waiting for Arnold was a city with a large

${ }^{54}$ Randall, Benedict Arnold: Patriot and Traitor, p. 406. ${ }^{55}$ Continental Congress, Journals, Volume XI, p. 571. 
neutral Quaker population, Tories, Loyalists, spies, speculators, and many revolutionaries aching for revenge against those collaborators. Arnold reported to Washington in a letter dated 22 June 1778. "Your Excellency's favor of the 2lst, respecting the militia, I received at three o'clock this evening, and immediately had as many inhabitants collected at the coffee-house as I could notify. These volunteers and the four hundred men now at the enemy's rear will make a formidable body."56 Clearly Arnold was taking no chances of a British return.

Arnold selected Major David Solebury Franks, Major Matthew Clarkson, and Captain Allen McLean as senior aides. Neither Franks or Clarkson had any experience administering civilian affairs. ${ }^{57}$ Acting as Arnold's aide-de-camp, Franks, a native of Montreal who had broken with his Loyalist father while the Americans occupied that city and volunteered to work on Arnold's staff in 1776, went ahead "to find suitable residence for the general." 58

On June 19, 1778 Benedict Arnold and his staff of ten moved into his new headquarters at the Penn family mansion. From here Arnold used Continental Line troops to restore order to the city. He then opened the public food markets, and

${ }^{56}$ Benedict Arnold, Correspondence, Letters to Washington, January 1778-February 1779, Library of Congress.

${ }^{57}$ Flexner, The Traitor and the Spy, p. 222.

${ }^{58}$ Boatner, Encyclopedia of the American Revolution, p. 396. 
commanded that all "stores of merchandise be declared, and prohibited the transfer and sale of any goods of whatever nature until the identity and loyalty of the owners was established." ${ }^{59}$ Martial law was in effect.

Having prohibited all commercial trade temporarily, Arnold had complete and total control over the commerce of the city. ${ }^{60}$ On June 23rd, Major Franks received unlimited power by an unsigned order from Arnold to purchase or otherwise acquire East Indian or European merchandise without limit or restriction. Arnold promised payments with no definite statement of time. ${ }^{61}$ Since the commandant of the city should not be caught speculating, Arnold added to the agreement a strict provision that Franks hide "even from his most intimate acquaintances that the writer was concerned in the proposed purchases. " 62

The Monday following the declaration of martial law, Arnold was deep in commercial conference with clothier-General James Mease and his deputy, william West. With a firm grasp on the city and shrewd trade instincts, Arnold expanded the advantages derived from the closing of the shops. ${ }^{63}$ Arnold

${ }^{59}$ Sullivan, Benedict Arnold, Military Racketeer, p. 231.

${ }^{60}$ Ibid., p. 240.

61 Ibid., p. 241 .

62 Jared sparks, The Life and Treason of Benedict Arnold, Boston, 1835 , p. 189.

${ }^{63}$ Decker, Benedict Arnold: Son of the Havens, p. 301. 
signed an agreement with Mease and west that all goods included in public purchases, when not required for the army, would be sold for their own secret profit. ${ }^{64}$ The agreement stated "whereas by the purchasing goods and necessaries for the use of the public, sundry articles not wanted for the purpose may be obtained, it is agreed by the subscribers that all such goods and merchandise which are or may be bought, by the clothier-general, or persons appointed by him, shall be sold for the joint, equal benefit of the subscribers, and purchased at their risk." $" 65$

With unlimited opportunities for purchases at low prices, to say nothing of the power of confiscation, Arnold promptly came into a fortune. Later in a Congressional investigation of Mease during his tenure as Clothier General [in Philadelphia], it was discovered and reported that Mease misappropriated and disposed of $\$ 20,000$ without the knowledge and consent of Congress. ${ }^{66}$

Arnold, West, and Mease found that their arrangement was so advantageous that they decided to branch out into other areas. Buying $f l$ our at $\$ 5.00$ per barrel, Arnold arranged that it be transported to Somers Point at Egg Harbor, New Jersey and loaded aboard his merchant ship destined for Havana where

${ }^{64}$ Sullivan, Benedict Arnold, Military Racketeer, p. 251.

${ }^{65}$ Ibid. , p. 252.

${ }^{66}$ Journals of the Continental Congress, Volume XLV, Number 136 , Folio 763, Library of Congress. 
it sold for $\$ 23.00$ a barrel.$^{67}$

Profits from his Philadelphia schemes soon showed itself in Arnold's lifestyle. His household expanded to include a full staff of servants including a butler, washerwoman, housekeeper, coachman, and groom and a large four-wheeled, ornate carriage to carry him through the city. Arnold entertained lavishly and descriptions of the many dishes served, as well as the $£ 2,000$ spent on wine, were recorded by residents who made up the guest list. At one such soiree, Arnold proposed to French Ambassador Gerard that a joint naval expedition to the Caribbean under Arnold's command would be in their best interests. Gerard noted that "Arnold's naval ambitions were connected with the desire to carry off European merchandise." 68

Arnold also sought to curry favors from the ruling families of Philadelphia and regularly entertained Robert Morris, Blair MCClendon, and the shewell brothers. ${ }^{69}$ Robert Shewell conducted business at City Tavern and mingled freely with Tories, Loyalists, collaborators, and speculators. Shewell approached Arnold and suggested that as commandant of the city, he could solve a logistical business problem.

${ }^{67}$ Sullivan, Benedict Arnold, Military Racketeer, p. 253.

${ }^{68}$ Samuel Peters, "An Account of Benedict Arnold," Pennsylvania Magazine of History and Biography," Volume XXVI, 1877, pp. 139-143.

${ }^{69}$ Isaac Senter, The Journal of Philadelphia, New York, The New York Times and Arno Press, 1969 (originally published 1846), p. 213. 
Anchored in nearby New. Jersey was the Charming Nancy, a merchant ship belonging to shewell, william Constable, and william shurtliff. Her hold contained a full load of cloth, glass, metals, barrel staves, sugar, coffee, tea, paint, iron ore, and medicines. 70

Arnold, at a conference held at his residence, agreed to become a silent partner in return for half interest in the cargo and ship. For an immediate share of the cargo, Arnold received $\$ 8,000$. In return Arnold agreed to write a pass that permitted the free movement of shurtliff through the Atlantic seaboard. To retrieve the cargo of the Charming Nancy, Arnold ordered twelve teams of wagons from the Pennsylvania state Wagon Master to work on his behalf. 71

Arnold soon conducted more commercial than military business in Philadelphia. Drawing on the tremendous volume of public stores, Arnold speculated with public funds and invested his new capital in privateering operations. 72 A merchant who gave witness in a deposition to the supreme Executive Council of Pennsylvania stated that Arnold accepted $\$ 50,000$ to pay for clothing, but the merchant received nothing

${ }^{70}$ Ibid., p. 214 .

${ }^{71}$ State of Pennsylvania, Records of the Supreme Executive Council, Pennsylvania Colonial Records, Library of Congress, Washington, DC, State Records Section, Microform 86/6912E.

72 Boylan, Dark Eagle, p. 261. 
and was charged for the goods. ${ }^{73}$

By late 1778 Arnold's assets included ownership of the privateer General McDougall, a half share in the merchant ships Charming Nancy and Constable, and a three-quarter share of the sloop and cargo aboard the Active. In addition, he still possessed residential and commercial property in New Haven and warehouses in New London.

In March 1779, Arnold married Peggy Shippen, daughter of a prominent Tory, and as a wedding gift bought Mt. Pleasant, a 96 acre estate for $\$ 30,000 .^{74}$ Nathanael Greene commented on Arnold's recent acquisition to Colonel Jeremiah Wadsworth. "Arnold has lately bought a farm near the city of Philadelphia. It belonged to the MacPhersons. It is said he can have $£ 10,000$ for his bargain. If so, his trade is better than all commissary and quartermaster profits put together." 75

Military Governor Benedict Arnold's conspicuous tolerance of Loyalists and his continued involvement in speculative ventures infuriated radical Whigs in Pennsylvania. Favored treatment of prominent Tories brought Arnold under the close scrutiny of Joseph Reed, President of the Supreme Executive Council and a firebrand radical whig.

As criticism of Arnold's personal and public lifestyle Council.

${ }^{73}$ State of Pennsylvania, Records of the Supreme Executive

${ }^{74}$ Randall, Benedict Arnold, Patriot and Traitor, p. 468. ${ }^{75}$ Ibid. , p. 469. 
grew, he decided to resign his commission, obtain a grant of land in central New York, and live in seignorial splendor and seclusion. But before Arnold could realize his dreams, Reed published a series of charges of misconduct against Arnold. The eight charges:

"1. He gave permission to a vessel belonging to persons then voluntarily residing in this city with the enemy, and of disaffected character, to come into a part of the United states, without knowledge of the authority of the state, or the Commander-in-Chief.

2. In having shut up the shops and stores on his arrival in the city, so as to prevent officers of the army from purchasing, while he privately made considerable purchases for his benefit, as is alleged and believed. state.

3. In imposing menial tasks on sons of freemen of this

4. For that when a prize ship was brought into port by a brig of this state, whereupon a dispute arose respecting the capture, that would have amicably been settled by the claimants, General Arnold interposed, by an illegal and unworthy suit.

5. The appropriating of wagons of this state when called forth upon a special emergency to the transportation of private property, and that of persons who voluntarily remained with the enemy last winter, and were deemed disaffected to the interest and independence of America.

6. By a resolution of Congress giving exclusive power to recommend persons going within the enemy's lines, General Arnold eluded said resolve, wrote letters for Major Clarkson to cross enemy lines at Elizabethtown, New Jersey.

7. Failure of General Arnold to answer for the use of wagons within the state and failure to answer completely, satisfactorily, and respectfully to the Wagon Master of the state.

8. The discouragement and neglect manifested by General Arnold during his command to civil, military, and other characters who have adhered to the cause of the country, with an entirely different conduct towards those of another character too notorious to need proof or illustration. And, as such, this command has been supported by five thousand pounds per annum, we shall be very unwilling to pay any share of expenses thus incurred."

${ }^{76}$ State of Pennsylvania, Records of the Supreme Executive Council in the case of Major General Arnold, Microform 86/6914. 
By March of 1779 the charges came before a Committee of Congress, which deferred until the summer. Writing to Washington, Arnold attempted to explain the problems he faced. "Believe me my dear General, the whole is nothing more than the pretense and artifice to delay the matter, the final determination of which must make the President and Council appear to the world in their true colors, as a set of unprincipled, malicious scoundrels; who have prostituted their honor and truth, for the purpose of gratifying their private resentment against an innocent person."77

Arnold's court martial board convened at Dickerson's Tavern in Morristown, New Jersey on June 1 . Sitting on the board were General Robert Howe, General Henry Knox, Brigadier General William Smallwood, Brigadier General William Woodford, General William Irvine; and General Joseph Spencer. The Judge Advocate was John Laurence. ${ }^{78}$

The prosecution presented documents and evidence that described a history of abuse of power. Colonel John Fitzgerald testified that he spent the night at Mrs. Brockberry's Philadelphia lodgings with Major David Franks and saw papers on the desk from Arnold directing Franks to buy goods in

${ }^{77}$ Benedict Arnold, Correspondence, Letters to Washington, 17781779, Washington, DC, Library of Congress, pp. 290-291.

${ }^{78}$ Benedict Arnold, Proceedings of a General Court Martial of the Line, Held in the state of New Jersey, By Order of His Excellency George Washington Esq., General and Commander in Chief of the Army of the United States of America, For the Trial of Major General Arnold, June 1, 1779, Philadelphia, Frances Bailey, 1780, Library of Congress. 
Advocate was John Laurence. ${ }^{78}$

The prosecution presented documents and evidence that described a history of abuse of power. Colonel John Fitzgerald testified that he spent the night at Mrs. Brockberry's Philadelphia lodgings with Major David Franks and saw papers on the desk from Arnold directing Franks to buy goods in Philadelphia. ${ }^{79}$ Teamsters Jesse Jordan and David Cochrane testified that they were ordered to Egg Harbor by Arnold to collect wares from the Charming Nancy and then delivered them to stephen Collins, a Philadelphia merchant. Collins admitted under oath that he sold the goods on commission, paying half to Arnold and the remainder to William Constable, Robert Shewell, and James Seagrove. Also, receipts from a local miller in payment of services totaling $£ 1,000$ were checked to reveal that Arnold falsely billed the government and deposited the money into his account.

On January 28,1780 , Arnold was found guilty of violating Section 4 of the Articles of War, which forbade all acts "prejudice of good order and military discipline." 80 At the same time, the court absolved him of any intentional wrong-

${ }^{78}$ Benedict Arnold, Proceedings of a General Court Martial of the Line, Held in the state of New Jersey, By order of His Excellency George Washington Esq., General and Commander in Chief of the Army of the United States of America, For the Trial of Major General Arnold, June 1, 1779, Philadelphia, Frances Bailey, 1780, Library of Congress.

${ }^{79}$ State of Pennsylvania, Records of the Supreme Executive Council in the case of Major General Benedict Arnold.

${ }^{80}$ Benedict Arnold, Proceedings of a General Court Martial. 
doings and all illicit speculations, and sentenced him to receive a letter of reprimand from Washington. The severity of his Commander-in-Chief's words shocked him. "Our profession is the chastest of all. Even the shadow of a fault tarnishes the luster of our fine achievements. I reprimand you for having forgotten that, in proportion as you have rendered yourself formidable to our enemies, you should have been guarded and temperate in your deportment toward your fellow citizens." 81

Arnold resigned his governorship of Philadelphia in protest of his innocence and in doing so cut off his source of cash. Money that would otherwise been used to resolve debts became tied up in real estate and low-yield stocks. One by one his privateers were captured by British ships operating the blockade of the American coast. Because the British did not evacuate New York City or Newport, Arnold's speculative scheme of hidden merchandise failed to pay off, forcing him to sell off his privateer warehouse in New London and borrow $£ 12,000.82$

Arnold pressed Congress and the Board of Treasury for claims of back pay and expenses incurred during the Canadian invasion and Lake Champlain expedition. The Board of Treasury examined all accounts, receipts, and documents and issued a

${ }^{81}$ George Washington, Writings, 1745-1799, "April 6, 1780," John C. Fitzpatrick, Ed., Washington, DC, 1931 .

${ }^{82} \mathrm{New}$ London Historical Society Collection, Benedict Arnold Itemized Accounts, New London, ii, 122, 1933. 
who if he is credited by them must be charged and accountable of the United States.

That the credit of the sum of $£ 3,296,3 \mathrm{~s}, 4 \mathrm{~d}$ for sundry provisions, clothing, and purchased for use of the troops is for anything that appears to the Board a just credit.

Also, the credit of $\{416,16 \mathrm{~s}, 6 \mathrm{~d}$ the amount of the pay roll of the savages.

In the aforesaid sum of $£ 14,504,5 s, 7 d$ is included in the sum of $£ 1,000$ stated by the General to have been paid to John Halstead, Commissary of Provisions on the aforesaid expedition which sum the said John Halstead denies having received and refuses to account for unless the General can produce receipts."

Arnold stated that he did file vouchers in the Treasury Office, but a search failed to turn up any documentation. Arnold adamantly suggested that there was political conspiracy by the clerk, Mr. William Geddes, or one of the Commissioners of Accounts. An investigation into the alleged missing documents revealed that no one at the Treasury, Commission of Accounts, or any other Congressional offices witnessed the filing of the vouchers. The Board of Accounts charged Arnold for the missing $£ 1,000$.

The report concluded by stating:

"The Board concurs in the opinion with the Commissioners of Accounts that General Arnold's accounts and vouchers be reexamined by the Commissioners of Accounts at Albany, and that the present settlement be subject to such corrections and amendments as they shall report under which evaluation, and on principles aforesaid the Board states the General's account as follows.

Balance due to General Arnold in specie ....\$2,326."184 of the $\$ 66,000$ claimed by Arnold, the Treasury Board

${ }^{83}$ Journals of the Continental Congress, Treasury office Report, April 22, 1780, Washington, DC, Library of Congress, Volume XVI, pp. $393-396$.

$$
{ }^{84} \text { Ibid., p. } 397 \text {. }
$$


The report concluded by stating:

"The Board concurs in the opinion with the Commissioners of Accounts that General Arnold's accounts and vouchers be reexamined by the Commissioners of Accounts at Albany, and that the present settlement be subject to such corrections and amendments as they shall report under which evaluation, and on principles aforesaid the Board states the General's account as follows.

Balance due to General Arnold in specie .....\$2,326."84 of the $\$ 66,000$ claimed by Arnold, the Treasury Board would only reimburse him $\$ 2,326$. And, it further stipulated that this payment would be suspended until a complete review of his records could be completed. This slight on his personal honor incensed Arnold.

TURNING TRAITOR

Secretly Arnold had been corresponding with Major General Clinton at his headquarters in the Kennedy House in New York City since May of 1779. At the urging of his wife Peggy, Arnold wrote letters detailing his intent and his worth. Joseph stansbury, a crockery merchant from Philadelphia, and Jonathan Odel1, an Anglican pastor from New Jersey, brought letters from Arnold in Philadelphia to Clinton. Each letter contained good faith bits of intelligence about Washington's movements and, more importantly, the location of the French fleet. ${ }^{85}$

Long and complicated negotiations with Clinton bruised Arnold's ego. At one point in August of 1779, Arnold broke

${ }^{84}$ Ibid., p. 397.

${ }^{85}$ Decker, Son of the Havens, p. 351. 
off his correspondence, but quickly resumed it when a Philadelphia mob threatened his family. Major John Andre, aide to Clinton and chief of intelligence, handled Arnold during this period. Andre played on Arnold's inflated self-worth and self-pity and dug deeper for information about troop strength, fortifications, and deployment of French troops. Arnold offered at one point to surrender whatever troops or command he had to clinton when he was back on active duty.

Washington was eager to have Arnold back in action and, as early as his letter of reprimand, suggested furnishing him "as far as it may be in my power, with opportunities of regaining the esteem of your country."86 Arnold wanted the command of the fortifications at west Point, in the highlands of the Hudson River Valley. First Washington offered him command of the left flank of the Continental Army, but Arnold vigorously protested, claiming that his leg still suffered from wounds. Washington then offered command of West Point and Arnold accepted.

Washington ordered the construction of water batteries, redoubts, and a heavy chain at a sharp bend in the Hudson River, 60 miles from New York City. With the British controlling all sea lanes off the Atlantic coastline, communication between the northern colonies moved inland, and West Point became the slender thread that held the revolutionary fabric

${ }^{86}$ George Washington, Writings, 1745-99, John C. Fitzpatrick, Ed., Washington, DC, Volume 31, pp. 744-45. 
together.

On August 3, 1780, Major General Benedict Arnold assumed command of West Point. Prior to his departure from Philadelphia, Arnold received word of Clinton's acceptance of his terms of service. Referring to Arnold as "your partner", Andre penned the reply on July 25, 1780. "His excellency authorizes me to repeat in the strongest terms the assurances so often given to your partner that if he is in earnest and will to the extent of his ability cooperate with us, he shall not in any possible event have cause to complain. Essential services shall even be profusely rewarded, far beyond the stipulated indemnifications. " 87

The Clinton/Andre terms stated that "should we, through your means, possess ourselves of 3,000 men and [West Point] artillery, and stores, the sum of $£ 20,000$ should be paid to you." With his usual vigor and mercenary spirit, Arnold set about weakening the defenses of west Point and the surrounding batteries, as he prepared to switch sides.

Arnold also moved quickly to change his properties and schemes into cash. He sent urgent letters to connecticut agent Caleb Bull to collect unpaid reimbursements for his 1775 services to the state. He went to New Haven to sell his house, asking for $£ l, 000$ in gold or sterling bills from

${ }^{87}$ Randal 1, Benedict Arnold: Patriot and Traitor, p. 560.

$88 \mathrm{John}$ Bakeless, Turncoats, Traitors, and Heroes, Philadelphia, J.P. Lippincott Co., 1959, p. 158 . 
France, Holland, or England but was willing to settle for $£ 500$ if the property could not be sold quickly. ${ }^{89}$ To liquidate his smuggling assets in New York, Arnold went to Robert Bayard, Loyalist merchant, to transfer all funds and goods to London. ${ }^{90}$

As Arnold, angered at Congress for refusing to honor any claims for his seniority as Major General, weakened the defenses and dissipated troop strength at West Point, he also depleted the provisions, selling off anything of value at west Point. By doing so he negated the possibility of a long siege and turned a profit by requisitioning his share of provisions for the next six months and selling them on the open market. Arnold's aide-de-camp Major Franks complained that he refused to be Arnold's steward. 91

The flow of information from Arnold to clinton continued unabated from August until september when Andre insisted on a face-to-face meeting. On september 23,1780 after such a meeting, three militiamen, acting more as highwaymen than soldiers, captured Andre. They turned Andre over to the local commandant after discovering suspicious documents on him. Arnold, hearing of Andre's capture, hastily withdrew to the

${ }^{89}$ Carl Van Doren, Secret History of the American Revolution, New York, Viking Press, 1941, pp. 267-269.

${ }^{90}$ Justin G. Turner, Private Collection, Account Book of Robert Bayard, 1861, Philadelphia, Library of Congress special Collections.

${ }^{91}$ Sullivan, Benedict Arnold, Military Racketeer, p. 83. 
safety of the H.M.S. Vulture anchored below West Point.

Aboard the Vulture Arnold wrote to Washington.

"Sir: The heart which is conscious of its own rectitude cannot attempt to palliate a step which the world may censure as wrong. I have ever acted from a principle of love of my country, since the commencement of the present unhappy contest between Great Britain and the colonies. The same principle of love to my country actuates my present conduct, however it may appear inconsistent to the world, who very seldom judge right of any man's actions." 92

Arnold moved into Number 2 Broadway, next to British headquarters in New York, where he pledged to clinton on September 27,1780 to "think myself bound by every tie of duty and honor to retaliate on such unhappy persons of your army as may fall within my power, that respect due to flags, and laws of nations, may be better understood and observed." 93

In the first two weeks of British employ, Arnold joined in on a partnership with the British Agent of Transport, where he leased to the Crown his ship and invested $£ 1,148$ and gained a return of $£ 6,666.94$ For his treason, he earned $£ 6,000$ plus a commission of £315. In addition, as a cavalry colonel Arnold received a yearly pay of $\$ 450$, to be continued after the war at half pay, and, as a Brigadier General of Provincials for the duration of the war, received an additional $£ 200$. Arnold promptly sent a draft note to James Meyrick, a London investment banker, in the amount of $£ 5,000$ to be

92 "Arnold Letters," Magazine of History, Volume 3, 1906, p. 58. ${ }^{93}$ Wall ace, Traitorous Hero, p. 258.

${ }^{94}$ Ibid., p. 263. 
invested with the bankers of the Court for $£ 7,000$ in consolidated annuities at $4 \% .{ }^{95}$ In anticipation of commanding a regiment, Arnold sent a letter to Samuel Wallis of London, after making careful inquiries with British officers, to retain his services as a prize agent. ${ }^{96}$

\section{THE VIRGINIA AND CONNECTICUT OPERATIONS}

After a drum-head court martial, Major John Andre, late of His Majesty's $26 \mathrm{th}$ Regiment of Foot and deputy adjutantgeneral to the Commander-in-Chief Sir Henry Clinton, was summarily executed on October 2, 1780. In New York City Benedict Arnold, late commander of West Point, met with Sir Henry clinton to haggle over the bill for his failed attempt to turn over West Point. Clinton, depressed over the death of Andre and the general state of the war, rejected Arnold's pleas and remained firm. They had agreed to a payment of $£ 20,000$ if West Point had been surrendered with its garrison, $£ 10,000$ if the plot had failed, and $£ 6,000$ if the plot was discovered. Arnold, unhappy with the $£ 6,000$, wrote to clinton pressing the issue. "I have every reason to believe the step which I have taken will promote His Majesty's service more effectively than an expenditure of a like sum could possibly

${ }^{95}$ Isaac N. Arnold, The Life of Benedict Arnold: His Patriotism and Treason, Chicago, 1880, p. 149 .

${ }^{96}$ Wallace, Traitorous Hero, p. 292. 
have done in any other way."97 Arnold's plea fell on deaf ears, but his change in allegiance nonetheless brought him more money than any other American officer earned from the war.

Arnold's activities included self-promotion as he wrote a sweeping analysis of the conflict entitled "The Present State of the American Rebel Army, Navy, and Finances." Written in three weeks and addressed to the American Secretary, Lord George Germain, Arnold pressed for a vigorous prosecution of the war. He stated that Washington could be bought off with a title and that American soldiers could be persuaded to stop fighting if they received their back pay. But in his closing paragraphs, Arnold urged that a swift military operation in the highlands of New York and the Chesapeake region would stretch the rebel army beyond its limits. ${ }^{98}$ Also in the report to Germain, Arnold enclosed a letter petitioning the king for a pardon for his years of service as a rebellious subject. ${ }^{99}$

On October 7, 1780, Brigadier General Benedict Arnold issued a proclamation for volunteers from his headquarters in

${ }^{97}$ Sir Henry Clinton, The American Rebellion: A Narrative of His Campaigns, 1775-1782, London, 1787; reprint ed., New York, MacMillan, 1949, p. 889.

${ }^{98}$ Van Doren, Secret History of the American Revolution, p. 530.

${ }^{99}$ Ibid., p. 532 . 
New York. ${ }^{100}$ Arnold was given permission to raise a corps of cavalry and infantry. He hoped that Loyalists from New York, Long Island, New Jersey, and Connecticut would rally to him. While over 50,000 American Loyalists enlisted in the militia or served as regulars in the British Army, ${ }^{101}$ only 250 joined Arnold's Loyal American Legion.

Loyalists had felt the sting of the new radical turn of the War for Independence. Homes were looted and burned and farms and livestock confiscated as American patriots tried to expunge all vestiges of Loyalism and Toryism. The Loyalists became refugees seeking a safe haven in cities like New York and Newport or on parts of Long Island. From these ranks the Loyalist Corps and Provincial Regiments that fought for King George were actively recruited and encouraged to avenge themselves.

Governor Tyron and his Loyalist Corps of New York successfully raided Fairfield, New Haven, and Danbury. Meanwhile Loyalist Boards raised large sums of money, or, in the case of the Quakers, made clothes for the soldiers. 102 Arnold, in typical fashion, proposed several daring thrusts into enemy territory. First on his list was Philadelphia because of its seat of government and position as quartermaster center of the

${ }^{100} \mathrm{Claude}$ Halstead Van Tyne, Loyalists in the American Revolution, London, MacMillian, 1902, p. 188.

${ }^{101}$ Ibid., p. 171 .

${ }^{102}$ Paul H. Smith, Loyalists and Redcoats, University of North Carolina, 1964, p. 87. 
American Army. He proposed "driving the Congress from Philadelphia, destroying their supplies and ships on the river, and after, occupying the ground between Head of the Elk and Newcastle."103

clinton rejected the Philadelphia plan in favor of a Virginia incursion, putting Arnold in charge of a 1,600-man invasion force that was a part of a joint Army-Navy task force. Ten ships-of-the-linel04 transported Arnold's American Legion, the Queen's Rangers under Lt. Colonel John G. Simcoe, the Royal Edinburgh Volunteers commanded by Lt. Colonel Thomas Dundas, 80th Regiment of Foot, a detachment of Hessian Jagers under Captain Ewald, Colonel Beverly Robinson's Loyal Guides and Pioneers, and two batteries of Royal Artillery. Loyalists composed more than half of the total strength of Arnold's force, while the 80 th Regiment had a large portion of its recruits taken from jails. 105

Clinton neither trusted nor had confidence in Arnold's capabilities and ordered him to consult with Dundas and Simcoe, who were familiar with light infantry tactics, simcoe had experience in several successful cavalry raids north of

${ }^{103}$ Clinton, The American Rebellion, Vol. I, p. 895.

${ }^{104}$ Frederick Mackenzie, Diary, 1775-81, Cambridge, Harvard University Press, Vol. II, 1930, p. 459.

${ }^{105}$ Anthony D. Darling, Redcoat and Brown Bess, Ontario, Museum Restoration Service, 1972 , p. 63 . 
New York City between 1778-79,106 and on other "operations of consequence."107 Unknown to Arnold, Clinton issued both officers a blank commission to take complete command in the event of Arnold's "death or incapacity."108

The Virginia Task Force embarked on December 11, 1780 and on the 20 th anchored off Sandy Hook waiting for favorable winds. A few days prior, Arnold had engaged Thomas Charles Williams of New York City as his prize agent. Annold also consulted with Commodore Sir George Collier and General Edward Matthew for advice on how best to dispose of prizes taken during the operation. 109 During the month-long voyage to the Chesapeake, Arnold also met with Captain Thomas Symons, naval commander of the task force, and came to an agreement as to how best to share prize money. 110

On the 2lst the expedition of 50 vessels sailed from Sandy Hook and encountered a violent storm. Most of the ships managed to sail to the Virginia Capes and reassembled on the 26 th and 27 th. Symons captured a few smaller merchant vessels in Hampton Roads on December 30, 1780. Arnold promptly pressed them into service for transporting his troops upriver.

${ }^{106}$ Lt. Col. John G. Simcoe, Queen's Rangers, New York, Bartlett and Welford, 1844, p. 168.

${ }^{107} \mathrm{Clint}$, The American Rebellion, Vol. II, p. 52. ${ }^{108}$ Ibid., p. 54 .

${ }^{109}$ Boatner, Encyclopedia of the American Revolution, "MatthewCollier Raid," May 1779, p. 1149.

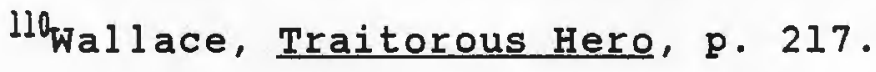


On the 4 th of January 1781, Arnold disembarked at Westover, Virginia and marched toward Richmond with a force of 800 and with Simcoe's Rangers at the flanks. At Four Mile Creek Arnold called a halt to the march on the 5 th and camped for the night. In Westham, seven miles upriver from the main camp, detachments of Simcoe's Rangers and the 80 th Regiment discovered a cannon foundry, boring mill, magazine, and a supply building, which were all put to the torch.ll An estimated six tons of musket powder was thrown in the river. ${ }^{112}$ A driving rain kept the Virginia militia from organizing an effective counterstroke.

On the 7th of January, Arnold's small privateer fleet, which had been ranging the local rivers and tributaries, captured a number of tobacco-laden vessels on the Appomattox River above the village of Broadway. 113 Baron Von steuben, the ranking Continental officer in Virginia, apprised of the situation tried to mount an orchestrated defense of the capital. 114

Five miles from Richmond, Arnold stopped at the ancestral home of the Byrd family, relations of his wife Peggy Shippen.

Ill Francis R. Lassiter, "Arnold's Invasion of Virginia," Sewanee Review 9 (1901): 78-93.

${ }^{112}$ Ibid., pp. 185-203.

113 Virginia Gazette, January 1781.

${ }^{114}$ Lt. Col. Banastre Tarleton, History of the Campaigns of 1780 \& 1781 in the Southern Provinces of North America, London, 1807; reprint ed., ARNO Press, 1968, p. 293. 
At dinner that night, Mrs. Byrd served up recent intelligence on Virginia troops' dispositions. Later, after the war, Mrs. Byrd's property and possessions were seized. She noted in one of her letters that "Arnold with a handful of troops marched about the country taking and destroying what he pleased, feasting with Tory friends and settling a regular correspondence with them."115

Arnold resumed his line of march toward Richmond, defended now by 200 militiamen. The defending patriots, tricked into thinking they saw a very large body of British regulars, broke ranks and ran. At 11 a.m., January 5th, 1781, Arnold took control of Richmond with 800 men, while establishing his headquarters at City Tavern on Main street where "he made the citizens feel the weight of his hand. The town was delivered over to plunder. "116

Before setting fire to the private warehouses, Arnold sent a proposition to Governor Jefferson, offering to spare the town on the condition that British ships be permitted to come up the James River unmolested and carry away the tobacco stores. 117

Reports filtering back to British headquarters in New York

${ }^{115}$ North Callahan, Royal Raiders: The Tories of the American Revolution, New York, Bobbs-Merrill Co., 1963, p. 135.

${ }^{116}$ George Green Shackelford, "Benedict Arnold in Richmond, January 1781, His Proposal Concerning Prize Goods," The Virginia Magazine of History and Biography, october 1952, pp. 592-600.

${ }^{117}$ George otto Trevelyan, The Concluding Part of the American Revolution, London, City Press Ltd., 1912, Volume I, p. 301. 
from various junior officers in the field described the unmilitary nature of the Arnold-Chesapeake expedition. In the diary of Frederick Mackenzie, a staff officer in the Royal Welch Fusiliers noted the following on February 1, 1781:

"At 10 o'clock arrived the Iris, 32 guns. Captain Dawson in 7 days from the Chesapeake with dispatches from Brigadier General Arnold and Captain Symons. That troops under Arnold's command have taken rebel stores at Peters burg, Richmond, and Westham. Arnold's reasons for not destroying the great quantities of tobacco and merchandise at Richmond and on board vessels in James River do not appear to me, to be good and sufficient."

Mackenzie's diary entry for February 2, 1781 states that "Arnold's Corps has taken about 700 hogsheadllg besides many other valuable articles."120

Judge Thomas Jones, Loyalist historian reported from New York that "Arnold has sent a sloop from Virginia loaded with sheep, geese, calves, turkeys, ducks, and other foodstuffs, as a gift for his wife. It is also believed that he has sent large quantities of tobacco to the West Indies to be sold for personal profit." 121

Letters from Major Baurmeister, Adjutant-General of Hessian Forces in the Virginia expedition, to his commander,

118 Frederick Mackenzie, A Daily Narrative of His Military Service As An Officer of the Regiment of Royal Welch Fusiliers, Volume II, Harvard University Press, Cambridge, 1980, p. 459.

119 A hogshead of tobacco weighed 500 pounds and was five feet in diameter.

120 Mackenzie, Diary, P. 466

121 Thomas Jones, History of New York during the Revolutionary War, edited by E.F. delancey, New York, Volume II, 1879, p.453. 
Baron von Jungkenn, state that "General Arnold, it seems, at first intended to go to Fredricksburg, but marched down to Petersburg instead, where according to reports he took possession of large tobacco stores." 122

One local resident who noted the actions of Arnold's riverine force wrote to a friend about the pillaging that was going on close to his home. John Bannister described to Theodore Bland,

"The militia are to the amount of two hundred with Baron steuben at Coggins point, and it appears are about to move from this place to that in a few days. We shall be able to circumscribe them. They (the British) are at present employed in taking tobacco at smithfield. In their way they called at Hog Island and from there began their movement to the scene of present rapine."123

From January till June, Arnold pressed his troops to scavenge the Virginia waterways. The list of towns that fell victim to Arnold included Hood, Hardings Ferry, sleeping Hole, Petersburg, Manchester, Sheffield, Powhatan, Burrells Ferry, Osburn, and Portsmouth. In a letter to Washington, General von steuben reported the condition of the state capital after Arnold withdrew. "A great part of the inhabitants having removed from their houses, found them plundered by the

${ }^{122}$ Major Karl Baurmeister, Confidential Letters and Journals, 1776-1784, translated and edited by Bernhard $A$. Uhlendorf, Rutgers University Press, 1964, p. 73.

${ }^{123}$ John Bannister, Letters to Theodore Bland, January and February 1781, The Bland Papers, Virginia State Archives, MSS 2B22546. 
soldiers." 124

Ordered by clinton to consolidate his position at the mouth of the James River, Arnold moved to fortify the town of Portsmouth and reinforce General Alexander Leslie's position along the forward post at Yorktown. Arnold was reminded by clinton not to take unnecessary risks, however, the raids on Richmond, and the surrounding countryside had been Arnold's own idea, giving the combatants of both sides a taste of the kind of light infantry warfare he advocated. 125

Arnold's military activities in the Chesapeake can be considered extremely successful. Less than three months after his defection Arnold was given command of an invasion force, and with his usual vigor swept through the James River valley destroying military stores, looting businesses, and terrifying an unprepared populace. 126

Six days after the arrival of Lt. General Earl Cornwallis, Arnold was ordered back to New York. Cornwallis wrote to clinton:

"I have consented to the request of Brigadier-General Arnold to go to New York; he conceives that your Excellency wishes to attend you there, and his present disposition renders him unequal to the fatigue of service. He will represent the horrid enorimites which are committed by our privateers in Chesapeake-bay; and I must join my earnest wish, that some remedy may be applied to an evil which is

124 Frederick Kapp, The Life of Frederick William von Steuben, New York, 1859, Volume I, pp. 374-375.

${ }^{125}$ Randal 1, Benedict Arnold: Patriot and Traitor, p. 583.

${ }^{126}$ Harold A. Larrabee, Decision at the Chesapeake, Clarkson N. Potter Publisher, New York, 1964, p. 130. 
very prejudicial to His Majesty's service." 127

While LaFayette and steuben consolidated their strength on the James River, Arnold sailed to New York and on his return Mackenzie noted in his diary, "Arnold is come here: The love of money, his ruling passion, has been very conspicuous in Virginia." 128

The restless Arnold petitioned clinton in the early days of August for another command and another opportunity to attack the American supply bases at either Philadelphia, New London, or New Haven, Connecticut. Clinton ignored the pleas for reinforcements from Cornwallis and authorized Arnold to attack New London, Connecticut with a substantial force.

New London was the premier privateer base in the northeast that was home port to over 58 ships. Between 1776 and 1781 the privateers of New London captured 157 ships that were Elying the British ensign. 129 New London enjoyed a relatively quiet existence because of its inland bay and despite the fact that many British merchant ships were captured and made their way to New London.

With the increase of New London privateering, the presence

${ }^{127}$ Sir Henry clinton, clinton Papers, Correspondence Between General Sir Henry clinton and Lt. General Earl Cornwallis, J. Debrett, London, 1803, Correspondence of May 26, 1781, Library of Congress, Rare Books Collection.

${ }^{128}$ Mackenzie, Diary, p.540.

${ }^{129}$ Robert Owen Decker, The New London Merchants: The Rise and Decline of a Connecticut Port, (Ph.D. dissertation, University of Connecticut, 1986) p. 14. 
staff was in the southwest bastion screened by a triangular breastwork for protection. The central area was 150 by 110 feet surrounded by a face wall. A rampart was constructed 30 feet from the face wall with an open ditch surrounding the fort. A sally-port led to a covered way leading down to the open field by the river. Sauccisons, fascines, and abatis formed an embroidery of defensive works. The fort contained a variety of artillery pieces ranging from four pounders to twenty pounders that were brought up from privateer ships. ${ }^{13 i}$ Fort Trumball, across the river on the New London side fell far short of the original plans and could only be categorized as a water battery ${ }^{132}$ with a few light field pieces.

The formidable presence of Fort Griswold, and the well established observation and signaling system would not deter Arnold from the wealth of the prize ships anchored at the town pier in New London. Working with William Heron, a Tory spy, Arnold was told of the cannon firing signal system and was told that H.M.S. Hannah was tied at the town pier with her cargo valued at $£ 100,000.133$

At British headquarters in New York, Arnold carefully selected his assault force. He assembled a mixed group of

13: John J. Copp, Centennial Commission Report on the Battle of Groton Heights, New London Centennial Commission, New London, 1881, p. 23 .

$13 \hat{i}_{\mathrm{A}}$ water battery is a small earth work with light artillery pieces facing the open area of a river or seaway.

23 Arthur G. Sharp, "Spy Without Visible Cause," Military History, February 1993, p. 14. 
as a water battery ${ }^{132}$ with a few light field pieces.

The formidable presence of Fort Griswold, and the well established observation and signaling system would not deter Arnold from the wealth of the prize ships anchored at the town pier in New London. Working with William Heron, a Tory spy, Arnold was told of the cannon firing signal system and was told that H.M.S. Hannah was tied at the town pier with her cargo valued at $£ 100,000.133$

At British headquarters in New York, Arnold carefully selected his assault force. He assembled a mixed group of British regulars, Loyalists, and German mercenaries.

The British contingent included the 38 th Regiment; veterans of the war that included Lexington and Concord, Bunker Hill, the New York and New Jersey campaigns, the attack on Springfield and the defense of Newport. The 40 th Prince of Wales Volunteers campaigners in the New York and New Jersey at the Battles of Princeton, Brandywine, and the massacre of American troops at Paoli. The 54th Regiment experienced at amphibious assaults in Carolina and Connecticut. The Loyalist forces included the 3 rd Battalion of the New Jersey Volunteers, veterans of the New York and New Jersey campaigns. The Loyal Americans, who successfully stormed Fort Clinton and Fort Montgomery and were now part of Arnold's American Legion.

${ }^{132} \mathrm{~A}$ water battery is a small earth work with light artillery pieces facing the open area of a river or seaway.

${ }^{133}$ Arthur G. Sharp, "Spy Without Visible Cause," Military History, February 1993, p. 14. 
Five officers and 112 from the Hessian Jagers and a detachment from the Royal Artillery completed this expeditionary force. ${ }^{134}$

On september 6, 1781, at 10 a.m., two divisions of Arnold's New London Task Force landed on both sides of the mouth of the Thames River. The alarm signal of two cannon shots were fired from Fort Trumball by local militiamen which was promptly changed by a third shot fired from a British ship, indicating a prize ship was coming into port.

On the Groton side, elements of the 40 th, 54th, 3rd Battalion of New Jersey Volunteers, a detachment of Jagers, and a battery of cannons landed in two embarkations under the command of Lt. Colonel Eyre. Eyre was a true veteran of the American war since arriving in 1776 and an experienced field commander. Eyre advanced through a series of muddy fields to his objective, Fort Griswold. Recent intelligence provided by William Heron led Arnold to believe that Griswold was lightly defended and would fall if attacked.

On the New London side of the Thames, the $38 \mathrm{th}$, the Loyal Americans, the American Legion, and Jager sharpshooters landed a half mile upriver at Green Harbor Cove, just below the water battery at Fort Trumball. Arnold ordered Loyalist Captain Jonathan Frink, a native of nearby Pomfret, Connecticut, and Captain Millet to swing onto Smith Farm Road and advance

${ }^{134}$ Anthony Darling, Red Coat and Brown Bess, Ottawa, 1970, Appendix II, p. 78 . 
toward Fort Trumball. Arnold wrote his report to clinton in his saddle stating "I have the pleasure to inform your Excellency, that the sudden attack and determined bravery of the troops carried the Fort (Trumball)."135

At this point Arnold took command of the remaining elements and moved onto New London. There a small body of Captain John Morgan's militia company, lightly armed, were deployed on the stonington Road. A brief skirmish disbursed the New Londoners and Arnold moved to take the town. As Arnold rode at the head of the column, past water street, he pointed his sword at the stores and exclaimed "soldiers, do your duty!"136 on Bank Street, Arnold's Loyalist troops seized "an immense quantity of European and West Indian goods and found, intact, the cargo of the Hannah and the interned captain."137 observing the removal of merchandise from stores and warehouses, Hessian soldiers began to plunder homes along the waterfront. The Connecticut Gazette reported that one hapless Hessian soldier so laden with booty was captured because he could not catch up with the departing longboats. 138

135 Makenzie, Diary, p. 624.

${ }^{136}$ Charles Allyn, Battle of Groton Heights, New London, 1882, p. 24 .

${ }^{137}$ Carolyn Smith, September 6, 1781, New London Historical Society, New London, 1979, p. 11.

${ }^{138}$ Connecticut Gazette and Universal, New London, October, 1781 edition, New London Historical Society. 
Across the river at Fort Griswold, the professional soldiers of the 40 th and 54 th Regiments attacked a well entrenched enemy, considerably larger than was reported by Arnold's spies. After a vicious forty minute fight the fort was taken. Many of the officers commanding the assault were killed including Colonel Eyre. The colonial commander of the fort, Colonel Ledyard offered his sword in surrender only to be killed by a Loyalist soldier. A melee resulted from this act and Americans were killed as they tried to surrender their weapons. British officers stood between their men and the wounded Americans to stop the slaughter. 140

As the task force withdrew from New London 65 houses, 31 stores, 18 shops, 20 barns, and 9 public buildings were consumed by fire. The American defenders lost 82 men. ${ }^{141}$ The devastation was so severe that in 1792 the Connecticut General Assembly passed a resolution of appropriation to the town of New London granting them $\$ 101,000$ for war damages. 142 Safely back in New York, Arnold submitted his written report to Clinton. Much to the chagrin of the British commander-in-chief, the action in New London was one of the most costliest of the war with over 200 British, Loyalist, and

${ }^{14 \hat{A}} \mathrm{Allyn}$, Battle of Groton Heights, p. 30.

141 John Barber, Connecticut Legislative Report on the Destruction of New London and Groton, Connecticut, Connecticut Historical Collections, B. Hamben, New Haven, 1836, p. 51.

${ }^{14} \hat{i}_{\text {Record }}$ of the Connecticut General Assembly, state of Connecticut Archives, Volume IV, 1792, p. 367. 
consumed by fire. The American defenders lost 82 men. ${ }^{141}$ The devastation was so severe that in 1792 the Connecticut General Assembly passed a resolution of appropriation to the town of New London granting them $\$ 101,000$ for war damages. 142

Safely back in New York, Arnold submitted his written report to clinton. Much to the chagrin of the British commander-in-chief, the action in New London was one of the most costliest of the war with over 200 British, Loyalist, and Hessians killed, wounded, or missing. ${ }^{143}$

Arnold's official prize report claimed $£ 2,000$ for goods taken aboard ships at the dock. 144 unofficially, the remaining spoils made it to Arnold's New York prize agent where it was commented that "the New London spoils made Arnold rich as a nabob."145 Arnold had successfully exploited the military nature of the expedition and he had grown wealthy.

THE CLOSE OF THE WAR AND ARNOLD'S CANADIAN BUSINESS VENTURES As His Majesty's forces stood ready for an American siege of New York, Arnold reported to Clinton's headquarters in

${ }^{141} \mathrm{~J}$ ohn Barber, Connecticut Legislative Report on the Destruction of New London and Groton, Connecticut, Connecticut Historical Collections, B. Hamben, New Haven, 1836, p. 51.

${ }^{142}$ Record of the Connecticut General Assembly, state of Connecticut Archives, Volume IV, 1792, p. 367.

${ }^{143}$ Mackenzie, Diary, p. 627.

144 Randal1, Benedict Arnold: Patriot and Traitor, p. 588.

145 William Smith, Historical Memoirs of 1778-1783, edited by พ.H. Sabine, New York, reprinted 1971, p. 64. 
early October of 1781. Together, Arnold and his Tory friend and mentor, Judge William Smith, submitted a report for another bold expedition against Philadelphia. ${ }^{146}$ This would strike deep in rebel territory, at the very center of American commerce, capturing supply depots and munitions. At this point however, Clinton lacked the confidence to commit any men and risk weakening New York's defenses.

News of the surrender of Cornwallis at Yorktown with his 8,000 men reached New York on the $23 \mathrm{rd}$ of October. Two day later Arnold applied to clinton for permission to go to England. Arnold's activities during this war had made him the most despised and hunted man in America. Arnold knew his effectiveness as a military entrepreneur in America was over. He needed an environment of a sympathetic audience, men of vision, men who can shape the policy of a nation. Arnold was confident that his self-promotional skills and proven military experience could get him a command in a new effort against the American rebels.

With Judge Smith's help, Arnold prepared a detailed report about the conduct of the war, leading up to the defeat at Yorktown. Supported by letters of recommendation from Loyalists. Arnold boarded H.M.S. Edward and accompanied Cornwall is back to England. On December 8, 1781, Peggy Arnold and the children set sail on a civilian merchantman. Despite the fact that other dependents were jammed aboard, Peggy and the ${ }^{146}$ Randa11, Benedict Arnold: Patriot and Traitor, p. 591. 
children enjoyed a cabin to themselves as Arnold had paid $£ 500$ for this rather exclusive privilege. ${ }^{147}$

Arnold landed in Greenwich, England January 22, 1782 and immediately bought a house at Number 18, Gloucester Place, Portman Square, in a fashionable area of London. 148 Soon after settling in Arnold's friends at court arranged for an audience with George III. Armed with his report on the American war, Arnold impressed the king and his advisors with his depth of knowledge about the conflict, and his optimism for renewed military effort in America. In recognition of his service to the crown Arnold was awarded a yearly pension of £360 plus £100 for each of his children. With the king's support Arnold returned to his Portman Square home and began to formulate a plan to build a forty-gun frigate and sail into American waters in search of prizes. ${ }^{149}$ But the peace between America and Britain was holding and anti-Loyalist feelings were running high. Plans for renewed military operations against the former colonies were canceled.

The Arnold family settled into a pleasant routine of summering in Essex at a rented cottage and entertaining

${ }^{147}$ Decker, Son of the Havens, p. 430 .

148 John G. Taylor, Some New Light on the Later Life and Last Resting Place of Benedict Arnold, London, MacMillian, 1931, p. 57.

${ }^{149}$ Issac Arnold, The Life of Benedict Arnold, His Patriotism and Treason, Chicago, 1881, p. 233. 
lavishly at their Portman Square home. ${ }^{150}$ Arnold continued to manage his investments and look for other money making ventures. One such opportunity came when the Parliament agreed to compensate Loyal Americans who suffered losses during the war.

In 1783, Arnold petitioned Parliament for compensation of personal and property losses as a result of his allegiance to the crown. His claim of $£ 16,125$ was the single largest claim filed with the Royal Commission. In the affidavit, Arnold claimed $£ 5,000$ for his house in Philadelphia in addition to his two horses, large carriage, and slaves. ${ }^{151}$ In April of 1785, before the commission could review his claim, Arnold wrote the Treasury Board and withdrew his claim stating that General clinton had paid him a fair settlement for his troubles in America. ${ }^{152}$

That summer, Arnold bought, equipped, and crewed a new brigantine, the Lord Middlebrook, and set sail for Canada. 153 Arriving in Halifax, Nova Scotia on November 19, 1785, Arnold re-established old friendship with Judge William Smith who had resettled in crown territory. Throughout that first

${ }^{150} \mathrm{G}$. Tate, "Arnold's Investment of the British Subsidy," Magazine of American History, Volume II, Part I, 1878, p. 45.

151 Wilmat J. Eardley, Historical View of the Commission for Enquiring Into Losses, Services, and Claims of American Loyalists, 1815, Volume 6, Rare Book Collection, Library of Congress, p. 38. ${ }^{152}$ Ibid, p. 39.

${ }^{153}$ Arnold, Life of Benedict Arnold, His Patriotism and Treason, p. 107 . 
winter in Canada Arnold studied the colony and assessed its prospects for business opportunities. In 1786, Arnold purchased a house and three lots on Broad street in St. John and made further purchases of land from Jedediah Fairweather, Ebenezer and Ann Spicer, David McClure, Robert Merritt, Nathan Jones, and Thomas and Mary Bustin. He also leased from the city of st. John two water lots for pier construction on Sheffield street. Up the Nashawaak River, just outside of town, he bought a large farm and leased it to Daniel Lyman. ${ }^{154}$ -

Acting the part as the new gentry and 1 and baron, Arnold became active in the civic affairs of st. John, contributing money to the fire company and the digging of town wells. In Fredrickton, Arnold bought four house-sized lots on the south side of the common and built a warehouse. ${ }^{155}$ At the end of 1786, Arnold bought a lot on Main Street in St. John in Lower Cove, where he built and stocked a dry-goods store. He took on Munson Hayt as his business partner. ${ }^{156}$

In May of 1786, the Lord Middleton, went down in a storm and was immediately replaced by a ship, bought with cash, from Nehemiah Beckwith of Mangerville, New Brunswick. Arnold

${ }^{154}$ Benedict Arnold, Papers, Correspondence and Legal Documents, 1786-1795, New Brunswick Provincial Historical Document Collection, It ems 14-38.

${ }^{155}$ Benedict Arnold, Letters of Instruction to His Attorney Jonathan Bliss, October, 1786, New Brunswick Historical Society.

${ }^{156}$ Wallace, Traitorous Hero, p. 385. 
christened the ship, Lord Sheffield ${ }^{157}$ and sailed out to establish four trading stations at Campebello Island and Fredrickton.

The enormous amount of real estate, the expense of building and outfitting two merchant ships, and the cost of building and maintaining a trading company, was in stark contrast to the poverty claimed by Arnold as he left America at the end of the war. ${ }^{158}$

Arnold continued to build his trading empire in the Canadian maritime, speculating in lumber and fur and trading supplies with the ever growing Loyalist population. By the spring of 1787 Arnold purchased another ship, the George, to help with his growing business. During the summer of 1787 Arnold made the circuit from st. John to the Caribbean, to England and returned to st. John with his new deep-water merchant ship, the Peggy. 159

Arnold's home was soon filled with elegant furniture the likes of which St. John's residents had never seen. A sale of furnishings in 1791 revealed blue-damask covered sofas, matching drapes, mahogany dining room set for twelve, Wedgewood giltware, mahogany four post beds with feather mattresses

${ }^{157}$ Arnold Papers, Odell Collection, Lot Number 11770 , Museum of New Bruswick.

${ }^{158}$ Randall, Benedict Arnold: Patriot and Traitor, Arnold claimed that he had only 300 guineas to his name when he left for England on December 15, 1781., p. 590.

${ }^{159}$ Ibid, p. 600 . 
and matching furniture, cases full of books, blue glassware, oriental rugs, and a collection of fine wines. 160

While New Brunswick held many opportunities for Arnold,it also had many pitfalls. In 1787 Arnold admitted his relationship with the daughter of a sachem from a local tribe had resulted in the birth of a son. The following year a mysterious fire destroyed his st. John warehouse and all of its contents. Arnold promptly filed a claim against the insurance policy he had taken out just one month earlier. ${ }^{161}$ shortly thereafter Arnold purchased additional tracts of land in st. John from stephen Hoyt, Simon Jones, William Wright, Munson Hoyt, Anthony and Mary Egbert, David and Stavia Lymond, and Abithan and Mary Camp. ${ }^{162}$ On December 23, 1789, Arnold's attorney, Jonathan Bliss, filed papers declaring his client partner with half interest, paid in cash, in the coastal trading sloop Nancy, from Fristram Hillman. 163

As his business ventures in Canada soured, and his clientele eager to cheat him out of payment, Arnold set sail for London in 1791, never to return to Canada again. Returning to England, Arnold used his Canadian venture capital to purchase an additional house at Cavendish square, in the heart

${ }^{160}$ St. John Gazette, Sale of Arnold Furnishings, September 22 , 1791, st. John Historical Society.

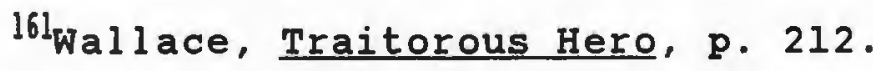

162Arnold Papers, Odell Collection, Land Transactions, Number 11772, Museum of New Brunswick.

${ }^{163}$ Ibid, Legal Documents, Number 11785. 
of London.

From July till September of 1791, Arnold received a series of bills of exchange from John Robinson, Acting Deputy Paymaster of the Royal Treasury. Totaling more than $£ 1,000$ sterling, the money was issued to Arnold for "support and service to His Majesty's forces in Canada."164

Using this money Arnold bought and armed a merchant ship and sailed for the West Indies. For more than a year Arnold cruised the Caribbean Islands and in June of 1794 sold his sugar cargo at $s t$. Kitts and recorded a profit of $£ 5,000.165$ He delayed returning to England in the hope that he would be assigned a military command in the current war with France. Rejected out of hand, Arnold returned to England in 1796 and continued to buy $l$ and on both sides of the Atlantic.

A letter from the Duke of Portland in 1798 announced that in recognition of his military service in America, the king was granting Arnold land in Canada totaling more than 13,400 acres. 166 With the receipt of this land, Benedict Arnold became the largest private landowner in Canada. ${ }^{167}$

${ }^{164}$ Benedict Arnold Papers, 1786-1795, New Bruswick Historical Document collection, Items 52 and 59 .

${ }^{165}$ Randa1 1, Benedict Arnold: Patriot and Traitor, p. 608 .

${ }^{166}$ Arnold's Letter of Award from the Duke of Portland, Facsimile Number 42-88, Loyalist studies Document, Library of the University of New Bruswick.

${ }^{169}$ Harold Criscrank, History of the City of $5 t$. John, University of New Brusnwick, st. John, 1984, p. 172 
Examining Arnold's business interests in 1797 showed that he was in possession of most of the real estate in the business district of St. John, four trading stations, four merchant ships, two London houses and one summer cottage. , Included in his personal portfolio was stocks on London banks, and local businesses and a substantial investment in the newly formed Bank of North America. 168

In 1800 Benedict Arnold was 59 years old, a stranger in his adopted country, shunned by the ruling class and scorned by the military. By now the old wounds and illnesses came back with a fury and the persistent cough he brought back from the West Indies developed into pneumonia. By February, 1801 his condition worsened after suffering a series of strokes. A delirious coma keep him locked between life and death. Attended by his wife, Benedict Arnold died June 14, 1801. He was buried seven days later in a crypt beneath the Church of st. Mary's, Battersea, London. 169 so few attended the service that a London paper made the passing comment that "Poor General Arnold has departed this world without notice, a sorry reflection this for the Pitts and other turncoats."170

${ }^{168}$ Arnold Papers, Odell Collection, Note to attorney on consolidation of business interests, March, 1789, Item Number 117781 .

169 Taylor, Some New Light on the Final Resting Place of Benedict Arnold, p. 50.

${ }^{170}$ London Post June 16, 1801, as reported in Taylor, Some New Light on the Last Resting Place of Benedict Arnold, p. 55-56. 


\section{CONCLUSION}

Benedict Arnold was shaped and influenced by a life that knew both prosperity and poverty, pride and public shame. Later in life, he would conduct his commercial adventures with all the energy and vigor of a personal crusade. To Arnold, success had to come in the form of visible wealth. In his pursuit of financial security, the object lessons of his youth became obscured in a cloud of mercenary outcomes. The sign that hung above his New Haven shop illustrated his commitment "For himself..."

Before the war, his success at smuggling west Indian goods enabled him to buy real estate in New Haven and New London, and invest in businesses and shipping throughout maritime Connecticut.

From the outbreak of the war, Arnold worked beyond his Connecticut commission and operational instructions to include the capture of Fort Ticonderoga and the establishing of a northern Continental army at the Canadian border. Employing provisioning principles used by the British Army Arnold extracted a percentage of all pay and commissary monies for his own use.

War offered Arnold many opportunities to capitalize on the confusion that invasion, battle, occupation, and retreat provided. As such the towns and villages in the path of the American invasion of Canada bore the brunt of the looting and 
pillaging that became so profitable for Arnold. What Arnold could not sell he used for other purposes, as Peggy Deblois discovered in the trunk sent by the would-be suitor.

His noble and heroic efforts at Ticonderoga, Quebec, and Valcour Island prevented the British from invading and splitting the colonies apart. But, his embezzlement of company funds, the systematic plundering of Canadian towns, and issuing bogus vouchers in Vermont, was a portent of things to come.

Controversy followed Arnold from the Canadian wilderness to the streets of Philadelphia, as accounts of his improprieties surfaced from various junior officers. One officer was so offended that he resigned his commission and conducted a campaign to hold Arnold accountable for his actions.

As military commander of Philadelphia, Arnold was given the powers of martial law, and used them to procure and impound trade goods and then sell them in other cities, for inflated prices. Philadelphia was a fishbowl, and Arnold's illegal actions became the object of scrutiny by the fanatical Whig committee of the Supreme Executive Council of Pennsylvania. His frequent and conspicuous business and social contacts with known collaborators, war profiteers, and Tories highlighted the fact that Arnold had a second agenda to his military appointment.

Smuggling and war profiteering paid handsomely, and the visible wealth Arnold desired manifested itself in items such 
as his mansion, handsome carriage, servants, slaves, and lavish parties. The scrutiny of the Executive Committee led to an inquiry and eventually a courtmartial. The stain of personal impropriety would never be removed.

By 1780, the negotiations with the British had been reduced to haggling over the price for turning traitor. As commander of West Point, Arnold undermined its defenses and made a profit by requisitioning and selling off supplies.

As a brigadier-general with His Majesty's forces, Arnold conducted a ruthless campaign in the Tidewater area of Virginia and the lower Thames River Valley in Connecticut. During these expeditions Arnold would remove everything of value, and then order the warehouses and stores burned. The convenience of the fire would cover up his crimes in Montreal, Valcour Island, Virginia, New London, and st. John. Moving with precision based on Tory and Loyalist intelligence, Arnold stripped the towns and sent the goods off to awaiting prize agents.

Despite claims of poverty and hardship, Arnold was able to provide comfort for his family while in British held New York and on the passage to England. One year after his emmigration, Arnold was living comfortably in a large city estate and overseeing the construction of a trading ship, all without the support of investors. That same year Arnold purchased large tracts of commercial and private property in Canada.

The sum total of his expenditures and investments in the 
18 months following the war, far exceed all the money paid to him for switching allegiances.

Arnold was captured by the notion that a successful man has an abundance of land by which he can base his wealth. The purchase of land, buildings, and ships drained him and left him land rich and cash poor.

The cash flow problems began early and mounted, as grand schemes fell far short of their intended objectives. The hope of a United Loyalist Empire in Canada failed to attract the wealthy immigrants from America. Instead, the poor, disenfranchised Loyalist refugee gravitated north, in the hope of remaining part of the English crown. The Loyalist that settled in st. John were money poor and relied on the generosity of the crown and on a basic system of barter. Arnold's hopes of being on the ascending curve of an economic boom proved fruitless.

Desperation turned to frustration, as Arnold brought legal action against those who could not or would not pay. The result was a great deal of animosity between the working class of st. John and its most famous resident.

Despite Arnold's accumulation of wealth during the Revolution, and his careful investment planning, his objective of financial independence and security for his family ran into serious problem by 1790. Deep pockets and several quick turnaround trading ventures prevented financial disaster.

The Canadian land Arnold worked so hard to manage into 
profit became a financial burden, and would continue to be so for his family until the last acre was sold in 1861.

All profitability of the trading business ended with Arnold's death. At that point the debts he acquired would become due and further drain the family resources. Financial security eluded the Arnold family forever. While on paper Benedict Arnold was enormously wealthy with land and business interests, he essentially was cash poor.

Arnold's theft of the towns and villages in Canada and America was a calculated venture supported by a criminal delusion that it was acceptable to steal in time of war.

His actions in Philadelphia unmasked his compulsive need for money and comfort, while West Point showed just how far he would go to make a profit.

Turning traitor and receiving the kings commission was viewed by Arnold as a legitimate excuse to take from the enemy. His success on the James and Thames Rivers provided him with the means, and the opportunity to start a business, build ships, buy land, and live comfortably in England.

When he died, hopeful Federalists started false rumors that the traitor was buried in his Continental uniform and that his last words were about the United States. But Arnold died in the void of the traitor, shunned and hated for what he was and what he could have been. Arnold's battlefield brilliance and inspirational motivation at Quebec, Valcour Island, and Beamis Heights provided him with an opportunity to 
be remembered as a hero of the American cause. Now his name has become synonymous with treason and treachery. As a result of his divorce of loyalties, Arnold must remain content with his modest resting place in the basement crypt at st. Mary's Church in Battersea. 


\section{BIBLIOGRAPHY}

Primary sources, unpublished

Boston Public Library, Boston, Massachusetts. Arnold, Benedict, Letters to Mrs. Knox, 1777-1778, Microfilm 30/35.

Connecticut state Archives, Hartford, Connecticut. Records of the Connecticut General Assembly, 1792, Facsimile Issue 58.

Clements, William L., Library, Ann Arbor, Michigan. Clinton, Sir Henry, Papers, 1780-1782, Microfilm Ser. No. 8A.

Library of Congress, Washington, D.C. Rare Books and Manuscript Division. Arnold Papers. Correspondence with Washington, 1777-1778. Proceedings of the General Court Martial of the Line, 1780. Journals of the Continental Congress, Treasury office Report. Journal of the Continental Congress, Folio 763 .

State of Pennsylvania, Records of the Supreme Executive Council, Pennsylvania Records for 1779-1780, Microfilm 6912/14.

National Archives, Washington, D.C. Papers of General Philip Schuyler, Correspondence 1776-1777, Microfilm 142/144.

New Brunswick, Provincial Museum, New Brunswick, Canada. Arnold Papers and Correspondence, Land Transactions Recorded and Deeded, 1785-1789, Microfilm 14/38.

New London Historical Society, New London, Connecticut. Arnold, Benedict, Itemized Account Book, 1778.

University of New Brunswick, st. John, New Brunswick, Canada. Loyalist Studies Department, Arnold, Benedict, Letter from the Duke of York, 1798, Microfilm 105.

Virginia state Archives, Richmond, Virginia. Bannister, John, Letters to Theodore Bland, Letters to Mrs Byrd, 1781-1782, Microfilm 55/62.

\section{Primary sources, newspapers}

Connecticut Gazette and Universal, 1779-1782.

New Brunswick Gazette, 1789-1790.

Virginia Gazette, 1780-1781. 
Primary sources, books and articles

Arnold, Benedict. Regimental Memorandum Book, Fort Ticonderoga, Museum Bulletin 14, 1981, 71-80.

Barber, John. Connecticut Legislative Report on the Destruction of New London and Groton, Connecticut. New Haven, 1836.

Baurmeister, Karl. Confidential Letters and Journals, 1776-1784. Translated by Bernhard A. Uhlendorf. New Brunswick, N.J., 1964 .

Clinton, Henry. The American Rebellion: A Narrative of His Campaigns, 1775-1782, New York, 1949. - Correspondence Between General Sir Henry Henry Clinton and Lt. General Earl Cornwallis, London, 1803.

Continental Congress, Journals. edited by Worthington C. Ford 1904-1937, VI, 237.

Eardley, Wilmot J. Historical View of the Commission for Enguiring Into Losses, Services, and Claims of American Loyalists, 1815, Rare Book Collection, Library of Congress.

Force, Peter. American Archives, 1837-1853, 4, Library of Congress.

Mackenzie, Fredrick A. A British Fusilier in Revolutionary Boston, 1775-1781, edited by Allen French, Cambridge, MA, 1930 .

Rush, Benjamin. Autobiography, edited by George W. Corner, Princeton, 1813.

Simcoe, John G. The Queens Rangers, New York, 1844; reprint 1968 .

Sparks, Jared. Correspondence of the American Revolution, 4 vols. Boston, 1837.

Tarleton, Banastre. History of the Camapigns of 1780 and 1781 in the Southern Provinces of North America, 1807; reprint Arno Press, 1968 .

Washington, George. Writings, 1745-1799, edited by John C. Fitzpatrick, vol 31, Washington, D.C. 1931. 
Secondary sources

Allyn, Charles. Battle of Groton Heights, New London, 1882.

Arnold, Issac. The Life of Benedict Arnold: His Patriotism and Treason, Chicago, 1880 .

Bakeless, John. Turncoats, Traitors, and Heroes, Philadelphia, J.P. Lippincott, 1959 .

Boatner, Mark. Encyclopedia of the American Revolution, New York, David McKay and Co., 1966.

Boylan, Brian. Benedict Arnold: The Dark Eagle, New York, W.W. Norton, 1973.

Brandt, Clare. The Man in the Mirror, Random House, New York, 1994.

Callahan, North. Royal Raiders: The Tories of the American Revolution, Bobbs-Merrill Co., New York, 1963.

Caulkins, Frances M. History of Norwich, Connecticut, published by author, 1866 .

Copp, John J. Centennial Commission of the Battle of Groton Heights, New London, 1881 .

Darling, Anthony D. Red Coat and Brown Bess, Museum Restoration Publishing, Toronto, 1972 .

Decker, Malcolm. Son of the Havens, Antiquarian Press, New York, 1932 .

Everest, Allan S. Moses Hazen and the Canadian Refugees in the American Revolution, Syracuse University Press, 1976.

Flexner, James T. The Traitor and the Spy, Little, Brown and Co., Boston, 1953.

Fortesque, J.W. History of the British Army, McMillan and Co. London, 1911.

Harris, William. An Account of the Burning of New London, New London Historical Society, New London, 1858. 
Hill, George. Benedict Arnold, Knickerbocker Press, New York, 1858 .

Jones, Charles Henry. History of the Campaigns for the Conquest of Canada in 1776, Philadelphia, 1882 .

Jones, Thomas. History of New York During the Revolutionary War, New York, 1879 .

Kapp, Friedrich. The Life of Fredrick William von Steuben, New York, 1859.

Larrabee, Harold. Decision at the Chesapeake, Clarkson N. Potter, New York, 1964.

Lassiter, Francis R. "Arnold's Invasion of Virginia," Swanee Review, 9, (1901): 78-93.

McClelland, William S. Smuggling in the American Colonies, Dawson and Co., New York, 1921.

Peters, Samuel. "An Account of Benedict Arnold," Pennsylvania Magazine of History and Biography, 25, (1877): 139-143.

Randall, William sterne. Benedict Arnold: Patriot and Traitor, William Morrow and Co., New York, 1990.

Rivis, R.G.L. "Tactics and Strategies of American Forces," Journal of the Society of Army Historical Research, 10, (1941): 101-102.

Rowland, Kate. Life of Charles Carrol1, New York, 1898.

Seuter, Isaac. The Journal of Philadelphia, (originally published 1846), reprinted by Arno Press, New York, 1969.

Shackelford, George. "Benedict Arnold in Richmond," Virginia Magazine of History and Biography, (October 1952): 591-600.

Smith, Carolyn. September 6, 1781, New London Historical Society, New London, 1979.

Smith, J.E.A. History of Pittsfield, Boston, 1869.

Smith, Justin. Our Struggle for the Fourteenth Colony, Canada and the American Revolution, G.P. Putnam, New York, 1907. 
Smith, Paul. Loyalists and Redcoats, University of North Carolina, 1964.

Sparks, Jared. The Life and Treason of Benedict Arnold, Boston, 1835 .

Sullivan, Edward Dean. Benedict Arnold Military Racketeer, Vanguard Press, New York, 1932.

Tate, G. "Arnold's Investment of the British Subsidy," Magazine of American History, II, (1878): 45-56.

Taylor, John G. Some New Light on the Later Life and Final Resting Place of Benedict Arnold, MacMillan and Co., London, 1931 .

Trevelyan, George otto. The Concluding Part of the American Revolution, MacMillan, London, 1912 .

Van Doren, Carl. Secret History of the American Revolution, Viking Press, New York, 1941.

Van Tyne, Claude $H$. Loyalists in the American Revolution, oxford Press, London, 1902.

Wallace, willard. Traitorous Hero: The Life and Fortunes of Benedict Arnold, Harper and Brothers, New York, 1954.

Wright, Marcus. "Benedict Arnold," Southern History Association, $(1906): 363-377)$. 